\title{
Implications of Full and Partial Retirement for Replacement Rates in a Defined Benefit System
}

\author{
Tunga Kantarc1 ${ }^{\mathrm{a}}$, Ingrid A.J. Smeets ${ }^{\mathrm{b}}$ and Arthur van Soest ${ }^{\mathrm{c}}$ \\ ${ }^{a}$ Department of Economics, Nijmegen School of Management, Radboud University, Thomas van Aquinostraat 5, \\ 6525 GD, Nijmegen, The Netherlands. \\ E-mail: kantarci@fm.ru.nl \\ ${ }^{\mathrm{b}}$ Department of Governing Board Consulting, APG Algemene Pensioen Groep N.V., Oude Lindestraat 70, 6411 EJ, \\ Heerlen, The Netherlands. \\ E-mail: ingrid.smeets@apg.nl \\ ${ }^{c}$ Department of Econometrics and Operations Research, Tilburg School of Economics and Management, Tilburg \\ University, Warandelaan 2, 5037 AB, Tilburg, The Netherlands. \\ E-mail: A.H.O.vanSoest@uvt.nl
}

Flexible retirement arrangements in which workers can retire abruptly or gradually at the age of their choice with higher retirement income as a reward for working more or longer fit well with the changes in life course patterns in the past decades and may help to keep pension systems sustainable in times of population ageing. We analyse the flexibility of an existing pension arrangement in the Netherlands, characterised by a subsistence-level pay-as-you-go state pension combined with a supplementary occupational pension. We use the actual rules of a large occupational pension fund, the state pension and the tax system to calculate net replacement rates at ages 60 to 70 in full and partial retirement scenarios. We find that partial retirement results in a smoother income path and encourages employees to defer their pension claims beyond age 65. Moreover, while occupational pensions give close to actuarially fair rewards for continued full-time or part-time work, the state pension does not. This makes postponing retirement less attractive for low-income groups in particular.

The Geneva Papers (2013) 38, 824-856. doi:10.1057/gpp.2013.25

Keywords: older workers; pensions; gradual retirement; phased retirement

Article submitted 15 January 2013; accepted 16 July 2013; published online October 2013

\section{Introduction}

The labour force participation and labour supply of older workers is at the top of the policy agenda in many OECD countries. Early retirement and other exit routes that lead to early withdrawal from the labour market endanger sustainability of the pension system and imply a burden for the macroeconomy, magnified by the ageing of the population. ${ }^{1}$ In many countries, generous early retirement programmes and other exit routes have been largely phased out over the past 10 years. Moreover, life course patterns are changing and the standard life course with abrupt transitions from education to work and work to retirement at an institutionally determined age applies less and less. ${ }^{2}$ Differentiation in the balancing of

\footnotetext{
${ }^{1}$ See, e.g. Latulippe and Turner (2000); Belloni et al. (2006).

${ }^{2}$ Brückner and Mayer (2005).
} 
market work and family responsibilities over the life course and individualised patterns with, for example, life-long learning and gradual retirement or bridge jobs have become more common, first in the U.S. and later also in Europe. ${ }^{3}$ The growing services sector is facilitating flexible work schedules and could increase especially part-time employment among older workers. ${ }^{4}$ More flexibility in allocating working time over the life course can prevent the excessive time squeeze in the period when workers bear substantial family responsibilities and, in particular, can help women to remain attached to the labour force, thereby maintaining their human capital and raising their labour force participation when the children have grown up. ${ }^{5}$ The fact that more and more people remain in good health much longer creates opportunities for a "fourth pillar" pension in the form of human capital and earnings after the current standard retirement ages, but the extent to which this is exploited depends upon individual as well as institutional factors. ${ }^{6}$

The current policy debate focuses on increasing flexibility and allowing individuals to choose their desired retirement scenario from a set of actuarially fair options. ${ }^{5}$ This implies limiting mandatory retirement or other impediments to working after a given standard age and removing obstacles for gradual retirement, such as financial disincentives in the pension system or the tax rules, or rules in the state or occupational pension system that hamper combining part-time work with receiving a partial pension. ${ }^{7}$ This may have important consequences for the labour supply of older age groups, since the literature suggests that retirement decisions are sensitive to financial incentives. ${ }^{8}$ Gradual retirement in particular has the potential to improve the lifetime utility of older workers by smoothing the transition from working life to a life with different activities, while at the same time increasing the sustainability of the pension system if it raises total hours worked. Several studies have analysed the impediments to gradual retirement in the U.S. ${ }^{9}$ and Europe. ${ }^{10}$

In this paper we analyse the financial incentives and disincentives for early and late abrupt and gradual retirement among Dutch employees entitled to an occupational pension from the largest pension fund in the Netherlands. The Dutch pension system mainly consists of a flat pay-as-you-go state pension at the subsistence level (for which everyone is eligible who always lived in the Netherlands), combined with supplementary occupational pensions mandatory for most employees, mostly defined benefit (DB). ${ }^{11}$ Early retirement schemes were introduced in the 1980 s and are slowly being phased out. ${ }^{12}$ After substantial reforms in the past 20 years, many pension funds, including the one we consider now, aim at maximum retirement flexibility with actuarially fair trade-offs: Employees can choose, but pay a fair price for retiring early or working fewer hours and are rewarded for working longer. On the other hand, the state pension system and features of the tax and benefit system make that the actuarial fairness of the occupational pensions does not necessarily translate into fair

\footnotetext{
${ }^{3}$ Moen and Sweet (2004).

${ }^{4}$ Reday-Mulvey (2002).

5 Bovenberg (2008).

${ }^{6}$ Engelhardt (2012).

${ }^{7}$ Dunnewijk (2002).

${ }^{8}$ See, e.g. Gruber and Wise (2004) or Euwals et al. (2010).

${ }^{9}$ Hurd (1996); Brown and Schieber (2003); Chen and Scott (2003); Hutchens (2010).

${ }^{10}$ Delsen and Reday-Mulvey (1996); Reday-Mulvey (2000); Wadensjö (2006); Kantarcı and van Soest (2008).

${ }^{11}$ Alessie and Kapteyn (2001).

${ }^{12}$ Euwals et al. (2010).
} 
826

trade-offs in terms of net replacement rates. Our main goal is to analyse to what extent a flexible occupational pension system that seems to put the incentives right $e x$ ante still has features that make working longer unattractive, reducing the labour force participation and labour supply of older workers.

We consider a hypothetical benchmark employee with a given earnings level, entitled to a full state pension. We calculate this worker's future pension entitlements using the actual rules of the state and occupational pension schemes and compute net earnings and pension entitlements using the current Dutch income tax rules. These amounts are used to calculate net pension income replacement rates and pension wealth accruals for various scenarios of earlier and later abrupt and gradual retirement. We focus on a benchmark case, but also consider the sensitivity of the net replacement rates for different earnings levels, career interruptions, household composition and the parameters of the underlying pension system.

We also consider gradual retirement scenarios, because gradual retirement may help to keep people employed longer and therefore reduce total claims of pension rights. Second, older Dutch workers are interested in working part-time before retiring fully, but appear to be restricted by labour market rigidities. ${ }^{13}$ Third, gradual retirement provides a smoother transition to full retirement in terms of income, but also daily activities, social contacts, etc., in line with a non-standard life course pattern that accommodates individual preferences. It may even be beneficial to health, since working part-time instead of not at all may help to limit the loss of cognitive skills, which is recently shown to arise with full retirement. ${ }^{14}$

Studies particularly close in spirit to our study include Forman and Scahill,${ }^{15}$ who calculate pension rights in full and partial retirement scenarios in a final average pay DB system. Munzenmaier and Paciero ${ }^{16}$ and McGill et al. ${ }^{17}$ calculate net replacement rates in full and partial retirement scenarios using observed pension entitlements in defined contribution and DB plans. Fouarge and Huynen ${ }^{18}$ and Euwals et al. ${ }^{12}$ calculate gross replacement rates for full retirement at early and normal retirement ages using observed data in the Netherlands. Unlike these studies, we also calculate pension rights and replacement rates beyond the statutory retirement age and show how these change with the rules of the pension system and with pre-retirement income and other worker characteristics.

The main results of this paper are the following. Partial retirement instead of full retirement results in a much smoother income path before age 65 and encourages employees to defer their pension rights beyond age 65 . Second, replacement rates differ substantially across employees with different earnings levels in the cases of early and late full retirement, and this difference is much less substantial in the case of gradual retirement. These replacement rate differences imply that gradual retirement is more attractive for employees with higher earnings. The replacement rates also change substantially in the case of career interruptions or changes in service length, household composition or the occupational pension accrual rate. Our analysis of pension wealth accruals suggests that the state pension

\footnotetext{
${ }^{13}$ Kantarc1 and van Soest (2008).

${ }^{14}$ Rohwedder and Willis (2010).

15 Forman and Scahill (2003), Scahill and Forman (2004).

${ }^{16}$ Munzenmaier and Paciero (2002).

${ }^{17}$ McGill et al. (2005).

${ }^{18}$ Fouarge and Huynen (2005).
} 
and the tax system make later retirement actuarially unattractive, and this distortion is somewhat smaller in the case of gradual retirement than for abrupt retirement.

The remainder of the paper is structured as follows. The next section introduces the Dutch pension and income tax systems. The subsequent section calculates net replacement rates and analyses them for changing parameters of the pension system. The final section concludes.

\section{The Dutch pension and income tax systems}

Retirement income in the Netherlands stands on three pillars: state pensions, occupational pensions and private pension savings. Participation in the first two pillars is mandatory. We do not consider the third pillar, because its share in retirement income is much smaller and its importance varies much more across individuals. ${ }^{19}$ In sections "An occupational pension scheme" and "The state pension scheme", we describe the first two pillars and how they are implemented in our scenarios.

All pension and tax rules and parameter values are for the year 2010 and are assumed to remain unchanged thereafter. Some pension and tax rules are different for cohorts born before 1950 or 1953, but we assume the cohort is younger. None of the parameters of the analysis depends on gender. For convenience, we refer to an employee in general as "he".

\section{An occupational pension scheme}

We base our analysis on the $\mathrm{DB}$ scheme of the $\mathrm{ABP}$ pension fund, the biggest pension fund in the Netherlands covering employees in the government and education sectors. The scheme is funded so that the pensions are financed from the premiums of the participants paid in the past and from the returns on the invested premiums. The scheme is an individual scheme in, principle, but for employees with a partner, it incorporates a widow's pension (and orphans pensions for children up to some age threshold). The widow's and orphans' pensions are not incorporated in our calculations of pension benefits, since they would involve another layer of complexity. ${ }^{20}$

The premium at age $t$ of type $i$ is calculated as follows:

$$
F T E_{t} \cdot P R_{i} \cdot\left(P I_{t}-S P O_{t, i}\right) .
$$

The full-time equivalent (FTE) is the ratio of actual, paid working hours to working hours in a full-time job at age $t$. The premium rate $(P R)$ is the contribution rate. It is shared between employee and employer and specific to the premium type (i). There are four types: The oldage and surviving dependants' pension $(O P / N P)$, surviving dependants' pension insurance $(A N W)$, disability pension $(A A O P)$ and flexible early retirement pension (VUT/FPU). For the four types of benefits, the respective PRs paid by the employer and employee are 14.91 and 6.39 per cent; 0.075 and 0.225 per cent; 0.3 and 0.1 per cent; and 1.45 and 2.25 per cent. $^{21}$ Pensionable income $(P I)$ is annual gross income on a full-time basis, including holiday

\footnotetext{
19 Alessie et al. (1997); Alessie and Kapteyn (2001).

${ }^{20}$ In case of a divorce, the other spouse may be entitled to part of the accumulated pension. This will not be taken into account in our calculations.

${ }^{21}$ The premium rate for the disability pension differs across sectors, but the rate we present applies to the majority of these sectors.
} 
allowance and end-of-year bonus. ${ }^{22}$ For part-time workers, it is obtained by dividing the actual earnings by their FTE. The state pension offset $(S P O)$ depends on the type of premium: For $O P / N P$ and $A N W$, it is $€ 10,500$ and for $A A O P$ it is $€ 18,200{ }^{23}$ There is no $S P O$ for $V U T / F P U$. Employees pay premiums for their occupational pension over the so-called premium base $\left(P I_{t}-S P O_{i}\right)$. $P I$ is reduced by $S P O$ because employees also pay premiums for state pensions.

We assume that our benchmark participant accumulates occupational pension rights from age 25 until age 65 . These accumulated rights are paid out as an annity after age 65 , according to the formula:

$$
\text { PA_op }{ }_{25-64}^{d}=\sum_{t=25}^{64} F T E_{t} \cdot A R_{-} o p_{t} \cdot\left(P I_{t}-S P O_{t}\right) .
$$

The accrual rate $\left(A R \_o p\right)$ is the rate at which the pension rights build up. The current rate is 2.05 per cent and we assume that it does not change throughout the period. ${ }^{24}$ Pension rights accrue over the premium base $\left(P I_{t}-S P O_{t}\right)$ and we assume that gross income is constant throughout the period when pension rights are accumulated. This is a stylised case since in reality, the age profile of gross income is usually not flat over the life cycle.

The scheme is an average salary scheme, with each year's salary contributing in the same way. Three specific issues regarding Eq. (2) need to be mentioned. First, the pension annuity depends on the domestic situation $(d)$. If the participant is not single when he first claims his pension rights, the amount in Eq. (2) applies and the participant's spouse is entitled to a survivor pension when the participant dies. If the participant is single when first claiming, the pension amount in Eq. (2) is increased by 6 per cent. Second, the accrual in Eq. (2) is increased by $€ 40.50$ in years in which the employee's gross income is less than $€ 28,031$. $^{25}$ Our calculations account for this supplement. Third, ABP aims to increase the pension annuities each year in accordance with wage inflation in the government and education sectors. The actual increase can be the same as, lower, or higher than the increase in the average wage, depending on the financial situation of the pension fund ("conditional indexation"). For example, on 1 January 2008, ABP increased the pension rights by 2.05 per cent, according to the average wage increase in that year, but also by an additional 1.96 per cent to compensate for the lack of increase in previous years, since its financial situation improved in 2008 (p. $16^{26}$ ). In our analysis we assume no increase in wages and no indexation. Our analysis can therefore be interpreted as an analysis of real wages under the assumptions of full indexation and equality of wage and price inflation.

\footnotetext{
22 In fact, this is not exactly true, because employers increase the annual gross income to compensate the employee for a certain type of transfer fee, but, to prevent that this raises employee's pension premiums, they reduce the gross income by the amount with which it is raised when calculating the pensionable income. Our calculation accounts for this adjustment. In particular, we assume below that the employee earns an annual gross income of $€ 30,000$ which is adjusted to a pensionable income of $€ 29,441$.

${ }^{23}$ Stichting Pensioenfonds ABP (2010a).

${ }^{24}$ The accrual rate changes only with specific policy changes. It increased from 1.75 to 2.05 per cent when ABP changed the final salary scheme to the career average scheme in 2004. Moreover, if SPO is increased (due to, e.g. an increase in the minimum wage), the accrual rate can be increased.

25 This is for full-time workers; the threshold and the amount of the supplementary pension rights depend on FTE (Stichting Pensioenfonds ABP, 2010b).

${ }^{26}$ Stichting Pensioenfonds ABP (2009).
} 
The first panel of Table 1 shows a retirement scenario for a hypothetical employee who starts contributing to the pension scheme at age 25 and works full-time (staying in the same scheme) without interruption until abrupt retirement at age 65 . His PI is $€ 29,441$, roughly the average gross income in the Netherlands. The employee builds up €388 every year, amounting to a gross occupational pension annuity of $€ 15,531$ at age 65 , as shown in the table. We denote this annuity as $P A \_o p_{25-64}^{d}$. The premium paid according to Eq. (1) is $€ 1,927$ per year.

The second panel shows a scenario where the employee works full-time $(F T E=1)$ until age 70 , and also defers his pension claims till age 70 . For his pension annuity at age 70 , this means two things. First, the annuity deferred at age 65 will rise due to the actuarial adjustment until age 70 to $P A \_o p_{25-64}^{d} \cdot A F \_o p_{70}$. The first factor is the pension annuity at age 65 given by Eq. (2); the second is the actuarial adjustment due to later claiming; the actuarial factor $A F \_o p$ depends on mortality rates and an interest rate. Table 2 shows the full set of actuarial factors for all retirement ages. The actuarial factor for age 70 is equal to 1.461 , increasing the deferred pension in our example by $€ 7,160$. Second, the pension annuity at age 70 will increase due to the additional rights accumulated at ages 65 to 69 and, due to the actuarial adjustment of these rights, to age 70 :

$$
P A \_o p_{65-69}^{d} \cdot A F_{\_} o p_{70}=\sum_{t=65}^{69} A R_{-} o p_{t} \cdot\left(P I_{t}-S P O_{t}\right) \cdot A F_{-} o p_{70} .
$$

In our example, the accumulated pension rights at ages 65 to 69 together with the actuarial adjustment to age 70 amount to $€ 2,836$. The total amount of the pension annuity at age 70 is $€ 25,528$ (see Table 1). Fiscal regulations require that the accrued pension rights do not exceed $P I$. The pension fund is required to pay out the pension rights once they reach the level of the PI. Our calculations take this fiscal limit into account.

The third panel of Table 1 shows a scenario where the employee retires and claims his full occupational pension at age 62. The pension rights accumulate from age 25 to 61 . We denote this annuity as $P A \_o p_{25-61}^{d}=€ 14,366$. Claiming the pension annuity earlier implies that it will fall due to actuarial adjustment to age 62. The actuarial adjustment factor $A F \_o p_{62}$ at age 62 is equal to 0.819 (Table 2) implying that, in our example, the pension annuity is only $€ 11,766$.

The final panel of Table 1 considers a scenario where the employee retires gradually, working half-time $(F T E=0.5)$ from age 65 until age 70 and retiring fully at age 70 . We assume that he claims half of his pension rights at age 65 and defers the other half until age 70. (In fact, fiscal regulations require that the fraction of the pension the employee claims be at most the fraction of the work time that the employee retires.) For his pension annuity at age 70, this has the following implications. The pension annuity after full retirement will be the mean of the pension annuities calculated above for abrupt retirement at age 65 and at age 70: $€ 20,529$. Moreover, during gradual retirement from age 65 till age 69, the pension annuity will be half of that for abrupt retirement at age 65: €7,766.

It is possible to trade off pension rights over the (partial) retirement years in an actuarially neutral way. The actuarial adjustments are computed in a similar way as above and depend on age (see Table 2). For example, consider the gradual retirement scenario above where the employee partially retires at age 65 and starts to receive pension rights of $€ 7,766$ every year. The employee could increase his pension rights by 20 per cent from age 65 until age 70 , 
Table 1 Scenarios of abrupt and gradual retirement

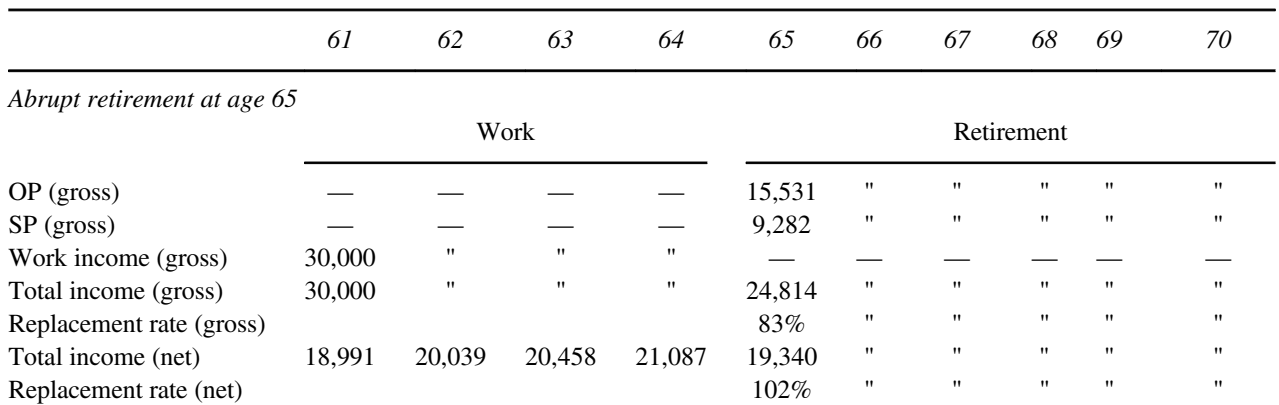

Abrupt retirement at age 70

OP (gross)

SP (gross)

Work income (gross)

Total income (gross)

Replacement rate (gross)

Total income (net)

Replacement rate (net)
Work

\begin{tabular}{|c|c|c|c|c|c|c|c|c|c|}
\hline- & - & - & - & - & - & - & - & - & 25,528 \\
\hline- & - & - & - & - & - & - & - & - & 12,457 \\
\hline 30,000 & $"$ & $"$ & $"$ & $"$ & $"$ & $"$ & $"$ & $"$ & - \\
\hline 30,000 & " & " & $"$ & $"$ & $"$ & " & $"$ & $"$ & $\begin{array}{c}37,985 \\
127 \%\end{array}$ \\
\hline 18,991 & 20,039 & 20,458 & 21,087 & 23,980 & " & 23,770 & $"$ & $"$ & $\begin{array}{c}26,657 \\
140 \%\end{array}$ \\
\hline
\end{tabular}

Abrupt retirement at age 62

OP (gross)

SP (gross)

Work income (gross)

Total income (gross)

Replacement rate (gross)

Total income (net)

Replacement rate (net)
Work

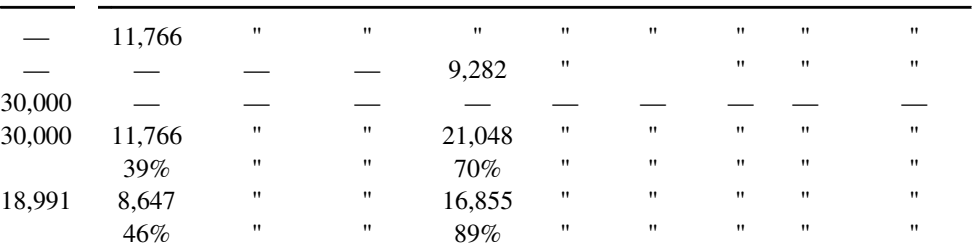

Gradual retirement from age 65 till age 70

\begin{tabular}{|c|c|c|c|c|c|c|c|c|c|c|}
\hline \multirow[b]{2}{*}{ OP (gross) } & \multicolumn{4}{|c|}{ Work } & \multicolumn{5}{|c|}{ Gradual retirement } & \multirow{2}{*}{$\frac{\text { Retirement }}{20,529}$} \\
\hline & - & - & - & - & 7,766 & $"$ & $"$ & $"$ & $"$ & \\
\hline SP (gross) & - & - & - & - & 4,641 & $"$ & $"$ & $"$ & $"$ & 10,870 \\
\hline Work income (gross) & 30,000 & $"$ & $"$ & $"$ & 15,000 & $"$ & $"$ & $"$ & $"$ & - \\
\hline Total income (gross) & 30,000 & $"$ & $"$ & $"$ & 27,407 & $"$ & $"$ & $"$ & $"$ & 31,399 \\
\hline Replacement rate (gross) & & & & & $91 \%$ & & & & & $105 \%$ \\
\hline Total income (net) & 18,991 & 20,039 & 20,458 & 21,087 & 22,098 & $"$ & 22,038 & $"$ & $"$ & 23,653 \\
\hline Replacement rate (net) & & & & & $116 \%$ & $"$ & $116 \%$ & $"$ & $"$ & $125 \%$ \\
\hline
\end{tabular}

Notes: (1) All amounts are in euros. (2) Ditto marks (") indicate the repetition of the amount presented next to it. (3) Parameter assumptions are the following: OP parameters: Pensionable income: $€ 29,441$. SP offset: $€ 10,500$. OP base: $€ 18,941$. Accrual rate: 0.0205. Domestic situation: Not single. Age started working: 25. Years of work at $65^{\text {th }}$ birthday: 40 . Pension trade-off: 0.00 . In the case of abrupt retirement at age 70, 100 per cent of OP is deferred. In the case of gradual retirement, 50 per cent of OP is deferred. SP parameters: SP base: 9,282. Accrual rate: 0.02 . Domestic situation: Not single. Age started insured: 15. Years of insurance at $65^{\text {th }}$ birthday: 50. In the case of abrupt retirement at age 70, 100 per cent of SP are deferred. In the case of gradual retirement, 50 per cent of SP is deferred. Work income parameters: Work income: $€ 30,000$. FTE during work: 1.00. FTE during gradual retirement: 0.50 . Deductions and compensations parameters (HI premium compensation domestic situation and Tax credit domestic situation): Single earner in couple. 
Table 2 Actuarial factors for earlier and later retirement than at age 65

\begin{tabular}{lcc}
\hline Retirement age & \multicolumn{2}{c}{ Actuarial factor } \\
\cline { 2 - 3 } & Occupational pension scheme & State pension scheme \\
\hline 60 & 0.724 & - \\
61 & 0.770 & - \\
62 & 0.819 & - \\
63 & 0.874 & - \\
64 & 0.934 & 1.000 \\
65 & 1.000 & 1.054 \\
66 & 1.074 & 1.114 \\
67 & 1.155 & 1.181 \\
68 & 1.246 & 1.256 \\
69 & 1.347 & 1.342 \\
\hline
\end{tabular}

Source: The actuarial factors of the occupational pension scheme are obtained from Stichting Pensioenfonds ABP (2010b). The actuarial factors of the state pension scheme are authors' calculation according to Ministerie van Sociale Zaken en Werkgelegenheid (2008).

implying a reduction by 9.2 per cent (20 per cent $\cdot(1.461-1))$ at age 70 for the remaining lifetime. ${ }^{27}$ This translates into a 6 percentage point increase in the net replacement rate from age 65 until age 70 and a 3 percentage point decrease at age 70 for the remaining lifetime. Hence, this effectively supplements the reduced earnings during gradual retirement, but also smoothes out incomes after age 65. The fiscal law imposes limits on the amounts that can be traded off: to avoid that the employee cashes an excessive amount in a few years, the ratio of the increased (decreased) annuity to the annuity that is decreased (increased) should be between $75 / 100$ and 100/75.

\section{The state pension scheme}

The General Old-Age Pensions Act (AOW) is the state pension scheme in the Netherlands, paying flat-rate benefits to people 65 years and older who have always lived in the Netherlands, independent of earnings, income or premiums paid. It should provide households in which the breadwinner is age 65 or older with a subsistence-level income. The only thing that therefore matters for the benefit level is household composition: individuals in couples each receive less than people living alone, and there are special allowances for children younger than 21 and one-earner couples in which only the breadwinner is age-eligible (see below). The scheme is unfunded and based on the pay-as-you-go principle so that current pensions are financed from the current premiums paid by workers. The premiums are paid as a percentage of work income through the income tax and labelled as national insurance premiums (see the section "The Dutch tax system"). Employees accumulate state pension

${ }^{27}$ For other ages, the actuarial factors in Table 2 can be combined. For example, if the pension is deferred from age 62 till age 67 instead of from age 65 till age 70, the adjustment factor is not 1.461 but 1.155/0.819=1.408. 
832

rights according to the formula:

$$
P A \_s p_{15-64}^{d}=\sum_{t=15}^{64} A R \_s p_{t} \cdot P B_{t}^{d} .
$$

Everybody who lives in the Netherlands is insured under this scheme. The maximum period of insurance is 50 years, from the $15^{\text {th }}$ to the $65^{\text {th }}$ birthday. For those who have not lived in the Netherlands all this time, the benefit is adjusted proportionally. The accrual rate $(A R)$ is 2 per cent per year. The pension base $(P B)$ is determined by the government according to the net minimum wage. It depends on the domestic situation $(d)$ of the retiree: single without a child $(€ 13,310)$, single with a child under 18 years old (€16,766), living with a partner who is older than 65 years old $(€ 9,282)$, living with a partner who is younger than 65 years old with $(€ 18,154)$ or without $(€ 9,282)$ supplementary allowance. The top panel of Table 1 shows that our benchmark employee who is living with a partner builds up $€ 186$ every year for a period of 50 years, leading to an annuity of $€ 9,282$ paid as of age 65 .

In 2008, the Dutch government put forward a draft law to promote employment after age 65 and to offset the financial effects of ageing. ${ }^{28}$ This law has not been implemented yet because of the ongoing discussion concerning the increase in the state pension eligibility age, but it is to be expected that a law that gives a similar kind of flexibility will be introduced in the future. We therefore will assume in our calculations that this law is in operation and that individuals who work beyond age 65 defer their state pension receipt until retirement (or age 70) to smooth their total income. The law allows an employee to defer part or all of his state pension rights for a maximum of 5 years. These rights are then actuarially increased at the time of claim. It is not possible to accrue additional rights during the deferral period. In the second panel of Table 1, we assume that the employee not only defers occupational pension, but also state pension receipt until age 70. As a consequence, the amount as of age 70 is 34.2 per cent higher than the standard state pension in the first panel. The factor 1.342 (taken from the right-hand column of Table 2) is equal to $A F_{-} s p_{65+N Y D}=L E_{65} /\left(L E_{65}-N Y D\right)$, where $L E_{65}$ is the average of the life expectancies of men and women at age 65, which was equal to 19.6 years in 2010 (according to Statistics Netherlands). The number of years of delay (NYD) is five in our example.

On the other hand, the law does not allow claiming state benefits before age 65 . This is why, in the third panel of Table 1, even though the worker retires at age 62 , he can only claim a state pension at age 65 .

In the gradual retirement scenario in the final panel of Table 1, the employee is assumed to claim half of his state pension rights at age 65 and defer the other half until age 70 . The righthand column of Table 2 also shows the actuarial factors for other possible ages of claiming. In the gradual retirement example, the actuarial revaluation increases the deferred state pension by $€ 1,587$ per year.

Note that the actuarial increase due to deferral of pension rights beyond age 65 is lower in the state pension scheme than in the occupational pension scheme, since the actuarial factors are lower (see Table 2). This is due to the fact that the actuarial factors of the state pension scheme are driven by mortality rates only, whereas those of the occupational pension scheme are driven by mortality rates as well as by returns on invested pension premiums. It seems

\footnotetext{
${ }^{28}$ Ministerie van Sociale Zaken en Werkgelegenheid (2008).
} 
difficult for the government to increase the actuarial factors to the level of those of the occupational pension fund, because the state pension system is unfunded, meaning that the government cannot generate returns on the premiums.

With an assumed gross income and the calculated occupational and state pension benefits, we can compute the gross replacement rates for the type of retirement scenarios presented in Table 1. For example, Table 1 shows that occupational and state pension benefits together replace 83 per cent of the full-time work income. Since the income tax rate in the Netherlands is substantially lower after age 65 , this does not immediately translate into how much the pension benefits replace previous earnings after the tax is accounted for. This is the topic of the next subsection.

\section{The Dutch tax system}

Every person who lives in the Netherlands and has some source of income is subject to income tax. Income tax is an individual system, with some specific allowances that depend on household composition and the income of other household members (see below). Besides, every person has to buy health insurance. An income-dependent subsidy or tax compensates low-income groups for regulated flat rate basic health insurance premiums and this is integrated with income tax and national insurance premiums. The lower panel of Table 1 shows the income after tax and health insurance premium payments, which we explain here in four steps. First, we determine the basis for wage tax and national insurance premiums according to the rules of the Dutch Tax Office (p. $80^{29}$ ). In particular, we first determine gross income, including (where applicable) work income, occupational pension benefits and state pension benefits, all on an annual basis, including holiday allowance, end-of-year bonus, etc. ${ }^{30}$ We then deduct the premiums paid to the occupational pension scheme, since these premiums are fully tax deductible $(€ 1,927 \cdot F T E$ per year for the four examples in Table 1). Other deductions and additions to the gross income include the tax deductible company savings scheme premiums, wage payments in kind and claims for future income, but in all our examples these are assumed to be zero. This gives the basis for employee insurance premiums. The deductions and additions to the basis for employee insurance premiums include life cycle savings scheme premiums and private car use, but these are assumed to be zero. This gives the basis for income-related health insurance premiums. Finally, we add the income-related health insurance premium to the basis for income-related health insurance premiums, because the employer fully compensates the employee for this premium, which is therefore treated as taxable income. This gives the basis for wage tax and national insurance contributions.

Health insurance premiums are determined as follows. Every income earner or pension receiver has to pay an income-related premium for regulated health insurance according to the formula:

$$
P R_{i} \cdot\left(G I_{i t}-P P_{t}\right) .
$$

${ }^{29}$ Belastingdienst (2010a).

${ }^{30}$ For income tax purposes, there are three types of taxable income: income from (current or past) employment and home ownership, income from a substantial interest, and income from savings and investments. We consider the former only. 
Table 3 Tax brackets and income tax and national insurance premiums rates

\begin{tabular}{|c|c|c|c|}
\hline \multirow[t]{2}{*}{ Bracket } & \multirow[t]{2}{*}{ Annual income range $(€)$} & \multicolumn{2}{|c|}{ Marginal rate (\%) } \\
\hline & & Age $<65$ & Age $\geqslant 65$ \\
\hline 1 & $0-18,218$ & 33.45 & 15.55 \\
\hline 2 & $18,219-32,738$ & 41.95 & 24.05 \\
\hline 3 & $32,739-54,367$ & 42.00 & 42.00 \\
\hline 4 & $\geqslant 54,368$ & 52.00 & 52.00 \\
\hline
\end{tabular}

Source: Belastingdienst (2010a).

Note: The national insurance premiums are for the old-age pension insurance (AOW), surviving dependants' pension insurance (ANW) and general exceptional medical expenses insurance (AWBZ) schemes.

The second factor is the basis for the premiums. Depending on the type of the premium, gross income $(G I)$ is either the income from full- or part-time work, in which case the income is reduced by the amount of the pension premiums $(P P)$, or it is the state or the occupational pension benefit, in which case $P P$ is 0 . The insured pays premiums over each source of income. The $P R$ is specific to the type of the premium (i). The PRs associated with the work income, occupational pension and state pension are, respectively, 7.05, 4.95 and 7.05 per cent. The maximum amount of each income-related health insurance premium is $€ 33,189 .{ }^{29}$ The employer fully compensates the insured for the premiums paid on the work income. This compensation is added to taxable income as explained above.

In addition, everyone has to buy basic health insurance from a private insurer at an income independent premium of about $€ 1,262$ for one person and $€ 2,524$ for a couple. ${ }^{31}$ The tax office will compensate the insured for the premiums paid if their income is low. For a person who is single, the compensation is $€ 1,262-(€ 527+0.05 \cdot($ Total income $-€ 19,528))$ if total gross income is less than or equal to $€ 33,743$. For someone with a partner, the compensation is $€ 2,524-(€ 976+0.05$ - (Total income $-€ 19,528)$ ) if total gross income is at most $€ 50,000 .{ }^{32}$ For the examples in Table 1 , this gives a compensation of $€ 1,024$ as long as the employee works full-time and $€ 1,154$ during gradual retirement.

Given the basis for the income tax and national insurance premiums, the amount of income tax and social premiums to be paid is determined according to the progressive tax brackets in Table $3 .{ }^{33}$ For example, the tax basis amount of $€ 30,053$ during full-time work before age 65 in Table 1 is taxed as $€ 18,218 \cdot 33.45$ per cent $+(€ 30,053-€ 18,218) \cdot 41.95$ per cent, which amounts to $€ 11,059$. The tax rates decrease by 17.90 percentage points after age 65 for the first two tax brackets, because old-age pension insurance contributions no longer apply after age 65 . The average tax rate increases with income due to the increase in marginal income tax rates over the brackets. Hence, retirees with low incomes have the lowest income tax as a fraction of their income.

\footnotetext{
${ }^{31}$ There is some variation in this flat-rate premium across insurers; the amounts we use here approximate the market average (Belastingdienst, 2010a). In our benchmark examples we assume that our employee is the sole breadwinner and pays health insurance premiums for the partner also.

32 Belastingdienst (2010b).

${ }^{33}$ For convenience we will use the term "tax (rate)" to refer to the sum of tax and national insurance premiums.
} 
Table 4 Tax credits

\begin{tabular}{|c|c|c|c|c|c|c|c|c|}
\hline \multirow[t]{2}{*}{ Credit type } & \multirow[t]{2}{*}{ Credit basis } & \multirow[t]{2}{*}{ Credit basis amount $(€)$} & \multicolumn{2}{|c|}{ Credit rate (\%) } & \multicolumn{2}{|c|}{ Credit amount $(€)$} & \multicolumn{2}{|c|}{ Credit maximum $(€)$} \\
\hline & & & Age $<65$ & $A g e \geqslant 65$ & Age $<65$ & Age $\geqslant 65$ & Age $<65$ & Age $\geqslant 65$ \\
\hline General tax credit & Tax basis & - & - & - & 1,987 & 925 & - & - \\
\hline \multirow[t]{2}{*}{ Employed person's tax credit } & Tax basis & $0-9,041$ & 1.737 & 0.807 & \multicolumn{2}{|c|}{$\mathrm{CB} \cdot \mathrm{CR}$} & - & \\
\hline & & $\geqslant 9,042$ & 11.888 & 8.779 & \multicolumn{2}{|c|}{$(\mathrm{CB}-9,042) \cdot \mathrm{CR}$} & 1,489 & 1,057 \\
\hline \multirow[t]{2}{*}{ Employed person's tax credit reduction } & Work income & $0-43,385$ & - & - & - & - & - & - \\
\hline & & $\geqslant 43,386$ & 1.250 & 0.581 & (CB-43 & 6) $\cdot \mathrm{CR}$ & 56 & 56 \\
\hline \multirow[t]{2}{*}{ Elderly person's tax credit } & Total income & $0-34,933$ & - & - & - & 684 & - & - \\
\hline & & $\geqslant 34,934$ & - & - & - & - & - & - \\
\hline Elderly single person's tax credit & - & - & - & - & 418 & - & - & - \\
\hline Single parent's tax credit & - & - & - & - & 945 & 440 & - & - \\
\hline Single parent's supplementary tax credit & Work income & - & 4.300 & 4.300 & \multicolumn{2}{|c|}{$\mathrm{CB} \cdot \mathrm{CR}$} & 1,513 & 705 \\
\hline \multirow[t]{2}{*}{ Combination tax credit } & Work income & $0-4,706$ & - & - & - & - & - & - \\
\hline & & $4,707-33,233$ & 3.800 & 1.770 & \multicolumn{2}{|c|}{$(\mathrm{CB}-4,707) \cdot \mathrm{CR}+\mathrm{FR}$} & 1,859 & 865 \\
\hline Work bonus & Work income & 0 & - & 9,041 & - & - & - & - \\
\hline Age $62 / 65$ & & $9042-55,840$ & 5.000 & 2.000 & \multirow{3}{*}{\multicolumn{2}{|c|}{$(\mathrm{CB}-9,042) \cdot \mathrm{CR}$}} & 2,340 & 936 \\
\hline Age 63/66 & & & 7.000 & 2.000 & & & 3,276 & 936 \\
\hline Age $64 / 67$ & & & 10.000 & 1.000 & & & 4,679 & 468 \\
\hline
\end{tabular}

Source: Belastingdienst (2010a).

Notes: CB refers to the credit basis amount, CR refers to the credit rate and FR refers to a flat-rate credit. Single parent's tax credit: To be eligible for the credit the person should have no tax partner, have a child younger than 27 years old. Single parent's supplementary tax credit: To be eligible for the credit, the household should be receiving the single parent's tax credit and have income from work, and have a child younger than 16 years old. Combination tax credit: It amounts to $€ 775$ before age 65 and $€ 360$ as of age 65 . To be eligible for the credit, the person should be entitled to the single parent's supplementary tax credit, have income from work, have children under 12 years old and be single. Work bonus: To be eligible for the credit, the person should have income from work. The presented credit rates and the credit maximum amounts refer to those at ages 62,63 , $64,65,66$ and 67 . It is 0 at other ages. 
836

To determine the eventual amount of tax to be paid, we also need to account for some tax credits. See Table 4. Some of these provide a flat-rate amount (FR) while others are income related, and some of them depend on the domestic situation. The amount of a tax credit can never exceed the amount of tax to be paid (before subtracting the credit). The basis (CB) over which the income-dependent credits are calculated varies. For example, during full-time work before age 65 , our benchmark worker in Table 1 is entitled to a general tax credit of $€ 1,987$ and the maximum employed person's tax credit is $€ 1,489$. The work bonus amounts to $€ 1,467$ at age 63 ((€30,000-€9,042) 7 per cent), etc.

Given the pension premiums, taxes, tax credits, health insurance premiums and health insurance premium compensations calculated above, the net work income and retirement income are calculated by adding the tax credits and health insurance premium compensations and subtracting the pension premiums, taxes and health insurance premiums from gross income. Table 1 presents the results for the four scenarios we consider. ${ }^{34}$ In the next section, we discuss the implications of full and partial retirement for occupational pension rights, state pension rights and replacement rates, given the described pension and tax systems.

\section{Replacement rates and pension wealth accruals}

For a benchmark employee and selected retirement scenarios, Table 1 presented the gross and net replacement rates at the given parameters of the systems of state and occupational pensions and the Dutch tax system. In this section, we first make similar calculations for all retirement scenarios of abrupt retirement at ages from 60 to 70 and scenarios of gradual retirement with durations of $5,4,3$ and 2 years at each age from 60 to 65 . We then analyse the sensitivity of the replacement rates to several changes in the baseline values of preretirement earnings, career interruptions and associated service length, etc.

\section{Baseline analysis: Replacement rates}

Using the same parameter values as in Table 1, Table 5 presents the gross replacement rates, defined as the ratio of gross retirement income over gross work income (where retirement income includes work income in the case of partial retirement). Replacement rates are at the individual level and not at the household level, since pension arrangements are essentially individual and the taxable unit is also the individual. An analysis of replacement rates at the household level would make things much more complicated because of the many combinations of retirement scenarios of the two spouses that would need to be considered. The table shows that the gross replacement rate for abrupt retirement at age 65 is 83 per cent, which can be compared with the gross replacement rate of 88.1 per cent calculated by $\mathrm{OECD}^{35}$ using the national parameters and rules applying in 2008. Note that we consider only pension savings and ignore any type of personal savings. In fact, in the Netherlands, many people make mortgage payments and therefore have less income available for consumption during their working years, while they finish their payments and have more

\footnotetext{
${ }^{34}$ Details of the net income calculations are presented in Kantarce et al. (2011).

35 OECD (2011).
} 
Table 5 Gross replacement rates under baseline parameter values

\begin{tabular}{|c|c|c|c|c|c|c|c|c|c|c|c|}
\hline & \multicolumn{11}{|c|}{ Replacement rate at the indicated age } \\
\hline & 60 & 61 & 62 & 63 & 64 & 65 & 66 & 67 & 68 & 69 & 70 \\
\hline \multicolumn{12}{|c|}{ Full retirement age } \\
\hline 60 & 0.33 & 0.33 & 0.33 & 0.33 & 0.33 & 0.64 & 0.64 & 0.64 & 0.64 & 0.64 & 0.64 \\
\hline 61 & - & 0.36 & 0.36 & 0.36 & 0.36 & 0.67 & 0.67 & 0.67 & 0.67 & 0.67 & 0.67 \\
\hline 62 & - & - & 0.39 & 0.39 & 0.39 & 0.70 & 0.70 & 0.70 & 0.70 & 0.70 & 0.70 \\
\hline 63 & - & - & - & 0.43 & 0.43 & 0.74 & 0.74 & 0.74 & 0.74 & 0.74 & 0.74 \\
\hline 64 & - & - & - & - & 0.47 & 0.78 & 0.78 & 0.78 & 0.78 & 0.78 & 0.78 \\
\hline 65 & - & - & - & - & - & 0.83 & 0.83 & 0.83 & 0.83 & 0.83 & 0.83 \\
\hline 66 & - & - & - & - & - & - & 0.90 & 0.90 & 0.90 & 0.90 & 0.90 \\
\hline 67 & - & - & - & - & - & - & - & 0.97 & 0.97 & 0.97 & 0.97 \\
\hline 68 & - & - & - & - & - & - & - & - & 1.06 & 1.06 & 1.06 \\
\hline 69 & - & - & - & - & - & - & - & - & - & 1.16 & 1.16 \\
\hline 70 & - & - & - & - & - & - & - & - & - & - & 1.27 \\
\hline \multicolumn{12}{|c|}{ Partial retirement age } \\
\hline 60 (5 yrs) & $0.66^{*}$ & $0.66^{*}$ & $0.66^{*}$ & $0.66^{*}$ & $0.66^{*}$ & 0.73 & 0.73 & 0.73 & 0.73 & 0.73 & 0.73 \\
\hline 61 & - & $0.68 *$ & $0.68 *$ & $0.68 *$ & $0.68 *$ & $0.83 *$ & 0.78 & 0.78 & 0.7 & 0.78 & 0.78 \\
\hline 62 & - & - & $0.70^{*}$ & $0.70 *$ & $0.70 *$ & $0.85^{*}$ & $0.85^{*}$ & 0.84 & 0.84 & 0.84 & 0.84 \\
\hline 63 & - & - & - & $0.71 *$ & $0.71 *$ & $0.87 *$ & $0.87 *$ & $0.87^{*}$ & 0.90 & 0.90 & 0.90 \\
\hline 64 & - & - & - & - & $0.74 *$ & $0.89 *$ & $0.89 *$ & $0.89^{*}$ & $0.89 *$ & 0.97 & 0.97 \\
\hline 65 & - & - & - & - & - & $0.91 *$ & $0.91 *$ & $0.91^{*}$ & $0.91 *$ & $0.91 *$ & 1.05 \\
\hline 60 (4 yrs) & $0.66^{*}$ & $0.66^{*}$ & $0.66^{*}$ & $0.66^{*}$ & 0.40 & 0.71 & 0.71 & 0.71 & 0.71 & 0.71 & 0.71 \\
\hline 61 & - & $0.68 *$ & $0.68 *$ & $0.68 *$ & $0.68 *$ & 0.75 & 0.75 & 0.75 & 0.75 & 0.75 & 0.75 \\
\hline 62 & - & - & $0.70^{*}$ & $0.70^{*}$ & $0.70 *$ & $0.85^{*}$ & 0.80 & 0.80 & 0.80 & 0.80 & 0.80 \\
\hline 63 & - & - & - & $0.71 *$ & $0.71 *$ & $0.87 *$ & $0.87 *$ & 0.86 & 0.86 & 0.86 & 0.86 \\
\hline 64 & - & - & - & - & $0.74 *$ & $0.89 *$ & $0.89 *$ & $0.89^{*}$ & 0.92 & 0.92 & 0.92 \\
\hline 65 & - & - & - & - & - & $0.91 *$ & $0.91 *$ & $0.91^{*}$ & $0.91 *$ & 0.99 & 0.99 \\
\hline 60 (3 yrs) & $0.66^{*}$ & $0.66^{*}$ & $0.66^{*}$ & 0.38 & 0.38 & 0.69 & 0.69 & 0.69 & 0.69 & 0.69 & 0.69 \\
\hline 61 & - & $0.68 *$ & $0.68 *$ & $0.68 *$ & 0.42 & 0.72 & 0.72 & 0.72 & 0.72 & 0.72 & 0.72 \\
\hline 62 & - & - & $0.70 *$ & $0.70 *$ & $0.70 *$ & 0.76 & 0.76 & 0.76 & 0.76 & 0.76 & 0.76 \\
\hline 63 & - & - & - & $0.71^{*}$ & $0.71 *$ & $0.87 *$ & 0.82 & 0.82 & 0.82 & 0.82 & 0.82 \\
\hline 64 & - & - & - & - & $0.74 *$ & $0.89 *$ & $0.89 *$ & 0.88 & 0.88 & 0.88 & 0.88 \\
\hline 65 & - & - & - & - & - & $0.91 *$ & $0.91 *$ & $0.91 *$ & 0.94 & 0.94 & 0.94 \\
\hline 60 (2 yrs) & $0.66^{*}$ & $0.66^{*}$ & 0.36 & 0.36 & 0.36 & 0.67 & 0.67 & 0.67 & 0.67 & 0.67 & 0.67 \\
\hline 61 & - & $0.68 *$ & $0.68 *$ & 0.39 & 0.39 & 0.70 & 0.70 & 0.70 & 0.70 & 0.70 & 0.70 \\
\hline 62 & - & - & $0.70 *$ & $0.70 *$ & 0.43 & 0.74 & 0.74 & 0.74 & 0.74 & 0.74 & 0.74 \\
\hline 63 & - & - & - & $0.71 *$ & $0.71 *$ & 0.78 & 0.78 & 0.78 & 0.78 & 0.78 & 0.78 \\
\hline 64 & - & - & - & - & $0.74 *$ & $0.89 *$ & 0.84 & 0.84 & 0.84 & 0.84 & 0.84 \\
\hline 65 & - & - & - & - & - & $0.91 *$ & $0.91 *$ & 0.90 & 0.90 & 0.90 & 0.90 \\
\hline
\end{tabular}

Notes: The replacement rates with an asterisk (*) represent those during partial retirement. Assumptions about abrupt and gradual retirement as in Table 1: FTE before (partial) retirement is 1.00. Defer OP is 1.00. Defer SP is 1.00. FTE during partial retirement is 0.50 . Defer OP is 0.50 . Defer SP is 0.50 . The table shows the replacement rates before taxes and any contributions. 
838

income available for consumption during their retirement years. This means that personal savings might affect the amount of income available for consumption before and after retirement and hence, also the relationship between income and standard of living.

Table 6 presents the net replacement rates for the retirement scenarios in Table 5, defined as the ratio of net retirement income over net work income before age 60. Even though gross (work) income remains the same, net income may change with age in the last years before full retirement, due to the age-dependent work bonus (see Table 4) and due to the change in marginal tax rates at age 65 (Table 3). By taking work income before age 60 as the reference, we do not incorporate these changes in the replacement rates.

Table 6 shows that the baseline net replacement rate for abrupt retirement at age 65 is 102 per cent, which can be compared with the net replacement rate of 99.8 per cent calculated by OECD. ${ }^{35}$ Possible explanations for the difference are that the OECD does not account for health insurance premiums and health insurance premium compensations and changes in tax credits for the period 2008 to 2010 .

The upper panel of Table 6 shows that, before age 65, the net replacement rates are about 7 percentage points higher than the corresponding gross replacement rates in Table 5. The difference is due to the progressive nature of the tax system. After age 65 , the difference between gross and net replacement rates increases to between 13 and 20 percentage points. This is because the tax rate as of age 65 is lower than that before age 65, as shown in Table 3 . The lower panel of Table 6 shows that before age 65 the net replacement rates during partial retirement are about 10 percentage points higher than the gross replacement rates in Table 5 . As of age 65 , the net replacement rates are about 25 percentage points higher during partial retirement and about 20 percentage points higher during full retirement, compared with the corresponding gross replacement rates in Table 5 . The 5 percentage point difference owes mainly to the fact that during partial retirement the employee is granted the labour tax credit for participating in the labour market.

In the remainder, we focus on net replacement rates. The upper panel of Table 6 reveals the following results. First, as a standing policy goal, the pension system in the Netherlands aims to maintain the living standard of employees before retirement with a target net replacement rate of 100 per cent at age 65 . The table shows that, for our benchmark employee, the current pension system achieves this target level with a net replacement rate of 102 per cent at age 65. Second, the diagonal elements show that delaying full retirement results in progressively higher replacement rates. This is because the actuarial factors in Table 2 progressively increase (which is due to the progressive increase in the mortality rate with age). The progressively increasing actuarial factors then also progressively raise the occupational pension annuities and the state pension annuity. A direct implication is that the price of leisure increases with age, and the table demonstrates how much it increases in terms of the replacement rates. Third, before age 65 , retirement income consists of the occupational pension only, and the accumulated occupational pension rights are actuarially decreased because of early retirement. Consequently, the occupational pension replaces less than half of previous earnings at the assumed parameter values. Unless the beneficiary has additional means such as a third pillar pension scheme, early retirement before age 65 appears to restrict retirement income substantially. To some extent, the income gap during early retirement can be partially repaired by shifting a share of the occupational benefits from after age 65 to before age 65 in an actuarially neutral manner, smoothing total income over time. This will be discussed in the section "Income smoothing through the occupational pension". 
Table 6 Net replacement rates under baseline parameter values

\begin{tabular}{|c|c|c|c|c|c|c|c|c|c|c|c|}
\hline & \multicolumn{11}{|c|}{ Replacement rate at the indicated age } \\
\hline & 60 & 61 & 62 & 63 & 64 & 65 & 66 & 67 & 68 & 69 & 70 \\
\hline \multicolumn{12}{|c|}{ Full retirement age } \\
\hline 60 & 0.40 & 0.40 & 0.40 & 0.40 & 0.40 & 0.82 & 0.82 & 0.82 & 0.82 & 0.82 & 0.82 \\
\hline 61 & - & 0.43 & 0.43 & 0.43 & 0.43 & 0.85 & 0.85 & 0.85 & 0.85 & 0.85 & 0.85 \\
\hline 62 & - & - & 0.46 & 0.46 & 0.46 & 0.89 & 0.89 & 0.89 & 0.89 & 0.89 & 0.89 \\
\hline 63 & - & - & - & 0.49 & 0.49 & 0.93 & 0.93 & 0.93 & 0.93 & 0.93 & 0.93 \\
\hline 64 & - & - & - & - & 0.53 & 0.97 & 0.97 & 0.97 & 0.97 & 0.97 & 0.97 \\
\hline 65 & - & - & - & - & - & 1.02 & 1.02 & 1.02 & 1.02 & 1.02 & 1.02 \\
\hline 66 & - & - & - & - & - & - & 1.09 & 1.09 & 1.09 & 1.09 & 1.09 \\
\hline 67 & - & - & - & - & - & - & - & 1.17 & 1.17 & 1.17 & 1.17 \\
\hline 68 & - & - & - & - & - & - & - & - & 1.26 & 1.26 & 1.26 \\
\hline 69 & - & - & - & - & - & - & - & - & - & 1.32 & 1.32 \\
\hline 70 & - & - & - & - & - & - & - & - & - & - & 1.40 \\
\hline \multicolumn{12}{|c|}{ Partial retirement age } \\
\hline 60 (5 yrs) & $0.76^{*}$ & $0.76^{*}$ & $0.77 *$ & $0.78 *$ & $0.79 *$ & 0.92 & 0.92 & 0.92 & 0.92 & 0.92 & 0.92 \\
\hline 61 & - & $0.77 *$ & $0.78 *$ & $0.79 *$ & $0.80 *$ & $1.08 *$ & 0.97 & 0.97 & 0.97 & 0.97 & 0.97 \\
\hline 62 & - & - & $0.80^{*}$ & $0.80 *$ & $0.81 *$ & $1.10^{*}$ & $1.10 *$ & 1.03 & 1.03 & 1.03 & 1.03 \\
\hline 63 & - & - & - & $0.82 *$ & $0.83 *$ & $1.12 *$ & $1.12 *$ & $1.11^{*}$ & 1.09 & 1.09 & 1.09 \\
\hline 64 & - & - & - & - & $0.84 *$ & $1.14^{*}$ & $1.14 *$ & $1.14^{*}$ & $1.14^{*}$ & 1.16 & 1.16 \\
\hline 65 & - & - & - & - & - & $1.16^{*}$ & $1.16^{*}$ & $1.16^{*}$ & $1.16^{*}$ & $1.16^{*}$ & 1.25 \\
\hline 60 (4 yrs) & $0.76^{*}$ & $0.76^{*}$ & $0.77 *$ & $0.78 *$ & 0.46 & 0.90 & 0.90 & 0.90 & 0.90 & 0.90 & 0.90 \\
\hline 61 & - & $0.77 *$ & $0.78 *$ & $0.79 *$ & $0.80 *$ & 0.94 & 0.94 & 0.94 & 0.94 & 0.94 & 0.94 \\
\hline 62 & - & - & $0.80 *$ & $0.80 *$ & $0.81 *$ & $1.10^{*}$ & 0.99 & 0.99 & 0.99 & 0.99 & 0.99 \\
\hline 63 & - & - & - & $0.82 *$ & $0.83 *$ & $1.12^{*}$ & $1.12 *$ & 1.05 & 1.05 & 1.05 & 1.05 \\
\hline 64 & - & - & - & - & $0.84 *$ & $1.14^{*}$ & $1.14 *$ & $1.14^{*}$ & 1.11 & 1.11 & 1.11 \\
\hline 65 & - & - & - & - & - & $1.16^{*}$ & $1.16^{*}$ & $1.16^{*}$ & $1.16^{*}$ & 1.19 & 1.19 \\
\hline 60 (3 yrs) & $0.76^{*}$ & $0.76^{*}$ & $0.77 *$ & 0.44 & 0.44 & 0.87 & 0.87 & 0.87 & 0.87 & 0.87 & 0.87 \\
\hline 61 & - & $0.77 *$ & $0.78 *$ & $0.79 *$ & 0.48 & 0.91 & 0.91 & 0.91 & 0.91 & 0.91 & 0.91 \\
\hline 62 & - & - & $0.80 *$ & $0.80 *$ & $0.81 *$ & 0.95 & 0.95 & 0.95 & 0.95 & 0.95 & 0.95 \\
\hline 63 & - & - & - & $0.82 *$ & $0.83 *$ & $1.12 *$ & 1.01 & 1.01 & 1.01 & 1.01 & 1.01 \\
\hline 64 & - & - & - & - & $0.84 *$ & $1.14^{*}$ & $1.14 *$ & 1.07 & 1.07 & 1.07 & 1.07 \\
\hline 65 & - & - & - & - & - & $1.16^{*}$ & $1.16^{*}$ & $1.16^{*}$ & 1.14 & 1.14 & 1.14 \\
\hline 60 (2 yrs) & $0.76^{*}$ & $0.76^{*}$ & 0.43 & 0.43 & 0.43 & 0.85 & 0.85 & 0.85 & 0.85 & 0.85 & 0.85 \\
\hline 61 & - & $0.77 *$ & $0.78 *$ & 0.46 & 0.46 & 0.89 & 0.89 & 0.89 & 0.89 & 0.89 & 0.89 \\
\hline 62 & - & - & $0.80 *$ & $0.80 *$ & 0.49 & 0.93 & 0.93 & 0.93 & 0.93 & 0.93 & 0.93 \\
\hline 63 & - & - & - & $0.82 *$ & $0.83 *$ & 0.97 & 0.97 & 0.97 & 0.97 & 0.97 & 0.97 \\
\hline 64 & - & - & - & - & $0.84 *$ & $1.14^{*}$ & 1.03 & 1.03 & 1.03 & 1.03 & 1.03 \\
\hline 65 & - & - & - & - & - & $1.16^{*}$ & $1.16^{*}$ & 1.09 & 1.09 & 1.09 & 1.09 \\
\hline
\end{tabular}

Notes: The replacement rates with an asterisk (*) represent those during partial retirement. Assumptions about abrupt and gradual retirement as in Table 1: FTE before (partial) retirement is 1.00. Defer OP is 1.00. Defer SP is 1.00. FTE during partial retirement is 0.50 . Defer OP is 0.50 . Defer SP is 0.50 . The table shows the replacement rates net of taxes and any contributions. Other assumptions: Work income is 30,000. Domestic situation is not single. Service length is 40 years. Full-time equivalent during the career years is 1.00 . 
840

The lower panel of Table 6 first of all shows that, for the benchmark case considered, the current pension system achieves a net replacement rate of about 80 per cent during partial retirement. Second, the diagonal elements show that delaying partial retirement results in higher replacement rates in partial retirement. Delaying partial retirement also results in higher replacement rates in full retirement, but the size of the increase is lower than in the case of delaying full retirement, because only part of the pension rights are delayed at the time of partial retirement. Third, when we compare gradual retirement in the lower panel with abrupt retirement at the corresponding ages in the upper panel, we observe that, before age 65 , the replacement rates are about twice as large. This is because during gradual retirement, work income provides an additional source of income supplementing the partial occupational pension. In the case of full retirement before age 65 , the occupational pension constitutes the only source of retirement income and may provide insufficient means. The employee may prefer to partially retire to bring his replacement rate up to a sufficient level and smooth his income path towards full retirement at an age when he is eligible for the state pension. However, note that when gradual retirement ends before the employee attains the state pension age, there is a sharp fall in total income until when the employee starts to receive the state pension at age 65 . Therefore, in the remainder, we assume that gradual retirement does not end until the employee starts to receive his state pension at age 65 to smooth the income path. If partial retirement starts before age 65 and ends after age 65 , the part of the occupational pension annuity claimed when retiring partially is actuarially decreased, but the remaining part actuarially increased compared with the age 65 amounts. If the actuarial losses and gains cancel out, gradual retirement constitutes a costless substitute to abrupt retirement at age 65 . Forman and Scahill ${ }^{15}$ demonstrate a similar way of achieving actuarial neutrality in partial retirement in a final average pay DB system and argue that actuarial neutrality is essential to avoid an actuarial gain or loss as a result of paying benefits prior to full retirement so that the employee and the employer can agree on a partial retirement arrangement.

On the other hand, comparing gradual retirement in the lower panel with abrupt retirement at the corresponding ages in the upper panel shows that the difference between the replacement rates as of age 65 is smaller than that before age 65 . This is because, as of age 65 , the employee receives half of the state pension in the case of partial retirement in the lower panel, while he receives the full amount of the state pension in the case of full retirement in the upper panel. The state pension played no role in retirement income before age 65 . This suggests that in the case of full retirement as of age 65 , the state pension may sufficiently supplement the occupational pension so that the employee might not need to retire gradually to supplement his occupational pension with work income as much as he might need to before age 65 .

\section{Baseline analysis: Pension wealth accruals}

Table 7 shows the deviations in the accumulated net present values of the gross and net pensions compared with full retirement at age 60 . All amounts have been discounted to age 60 using an interest rate of 3 per cent per year and the same survival probabilities as used by the occupational pension fund. The present values of occupational pensions are net of the premium contributions paid by both employer and employee (see the section "An occupational pension scheme"). Similarly, present values of state pensions account for old-age social 
Table 7 Deviations from the net present value of pension income in full retirement at age 60

\begin{tabular}{|c|c|c|c|c|}
\hline & \multicolumn{4}{|c|}{ Deviations from the net present value of pension income at age 60} \\
\hline & Occupational pension (gross) & State pension (gross) & Total pension (gross) & Total pension (net) \\
\hline \multicolumn{5}{|c|}{ Full retirement age } \\
\hline 60 & 0 & 0 & 0 & 0 \\
\hline 61 & 593 & $-4,223$ & $-3,630$ & $-6,032$ \\
\hline 62 & 1,060 & $-8,021$ & $-6,962$ & $-11,507$ \\
\hline 63 & 1,904 & $-11,412$ & $-9,508$ & $-16,124$ \\
\hline 64 & 2,760 & $-14,352$ & $-11,592$ & $-20,030$ \\
\hline 65 & 3,677 & $-16,807$ & $-13,129$ & $-23,353$ \\
\hline 66 & 4,878 & $-18,957$ & $-14,079$ & $-27,448$ \\
\hline 67 & 5,963 & $-21,032$ & $-15,069$ & $-31,423$ \\
\hline 68 & 7,233 & $-23,011$ & $-15,778$ & $-35,081$ \\
\hline 69 & 8,464 & $-24,888$ & $-16,424$ & $-45,552$ \\
\hline 70 & 9,821 & $-26,627$ & $-16,806$ & $-52,399$ \\
\hline \multicolumn{5}{|c|}{ Partial retirement age } \\
\hline 60 (5 yrs) & 1,841 & $-8,403$ & $-6,562$ & $-8,760$ \\
\hline 61 & 2,732 & $-11,585$ & $-8,852$ & $-13,014$ \\
\hline 62 & 3,511 & $-14,528$ & $-11,017$ & $-17,253$ \\
\hline 63 & 4,573 & $-17,213$ & $-12,639$ & $-21,440$ \\
\hline 64 & 5,608 & $-19,616$ & $-14,008$ & $-25,148$ \\
\hline 65 & 6,747 & $-21,713$ & $-14,965$ & $-28,129$ \\
\hline
\end{tabular}

Notes: (1) The figures represent the deviations of the net present value of pension benefits received by workers retiring after age 60 from the net present value of the pension benefit in full retirement at age 60. (2) Present value calculations are based on an interest rate of 3 per cent and survival probabilities for year 2010 .

security premiums paid on income after age 60 (see the section "The state pension scheme"). The first three columns present differences in the gross amounts; the final column considers total net pension income after taxes, accounting for the (additional) income tax on (additional) pension income as well as the tax deductibility of pension premiums (see the section "The Dutch tax system"). ${ }^{36}$

Column 1 shows that for this benchmark individual, postponing retirement is actuarially attractive if only the occupational pension is considered and state pensions and taxes are ignored. The full retirement scenarios show modest increases in pension wealth for each year that retirement is postponed. Gradual retirement also gives positive accruals compared with abrupt early retirement, with accruals of delaying receipt of part of the pension that are proportional to the complete accruals. Column 2, however, shows much larger amounts of the opposite sign for the state pensions. The reason is twofold-until age 65 , continued fulltime or part-time work implies paying more old-age social security premiums, but does not lead to higher state pension benefits. After age 65, old-age social security premiums are no

${ }^{36}$ As explained in the section "An occupational pension scheme", we do not incorporate the widow and orphan pension entitlements linked to occupational pensions; the effects of these on the accruals will depend on the age difference between the employee and his spouse. 
longer paid, but postponing state benefit receipt reduces state pension wealth, because the reward is less than actuarially fair (see the section "The state pension scheme"). In case of early gradual retirement, the first effect is relatively most important, because no old-age social security premium is paid on income above a given threshold. Still, as for the occupational pensions, the accruals for gradual retirement largely correspond to those of abrupt retirement at an age in the middle of the period of partial retirement.

Column 3 adds up the accruals of the occupational and state pensions. The negative accruals in column 2 always dominate the positive accruals in column 1, so that postponing gradual or full retirement always leads to a loss in total net pension wealth before taxes. The final column of Table 7 shows that the tax system enlarges the negative accruals substantially, particularly for full abrupt retirement at older ages. The main reason is the progressive nature of the tax system based upon income per year and not lifetime income: postponing retirement leads to higher pension incomes paid out over a smaller number of years; the higher annual incomes are taxed more heavily, without compensation for the shorter period during which they are paid. Although overly generous early retirement occupational pensions have been removed, the negative accruals due to state benefit premiums without future rewards and tax rules still imply disincentives for working fulltime after age 60. Still, these disincentives may only have a limited effect: Since the state pension cannot be claimed before age 65 , liquidity constraints may prevent early withdrawal. Moreover, mental accounting may prevent most of those who would be able to draw on financial assets from doing so in order to be able to retire earlier.

For partial retirement we also find negative accruals that increase the more partial retirement is postponed. But, due to the smoothing of earnings and pension income, the effect is relatively limited compared with the abrupt retirement scenario. For example, consider partial retirement at age 65 with a 5 -year period of half-time employment $(-28,129$; the final number in the table). In terms of total labour supply, this scenario corresponds approximately to abrupt retirement at age 67 or age 68 . But these abrupt scenarios give even more negative accruals compared with the same benchmark of abrupt retirement at age $60(-31,423$ and $-35,081)$. This suggests that partial retirement gives a modest actuarial advantage that partially undoes the negative actuarial rewards for postponing retirement that are inherently present in the Dutch system of income taxes and old-age social security benefits and premiums.

\section{Income smoothing through the occupational pension}

The first deviation from the baseline cases in the previous subsection considers the use of the right to shift receiving part of the occupational pension over time in an actuarially neutral way, in order to smooth lifetime income. The section "Baseline analysis: replacement rates" explained that before age 65 occupational pension benefits constitute the only source of retirement income, and these benefits are actuarially reduced for early claiming. In fact, Table 6 showed that, before age 65 , the occupational pension replaces less than half of pre-retirement earnings. This results in a large gap in retirement income until the employee starts to receive state pension benefits at age 65 . To some extent the employee can avoid this gap by trading off pension rights over the retirement years, as explained in the section "An occupational pension scheme". The employee can claim higher occupational pension rights during early retirement years at the expense of reduced pension rights at a later age. Trading off pension rights in this manner allows for smoothing the retirement income path. In Table 8 we consider abrupt and 
Table 8 Net replacement rates when pension rights are traded off against future rights

\begin{tabular}{|c|c|c|c|c|c|c|c|c|c|c|c|}
\hline & \multicolumn{11}{|c|}{ Replacement rate at the indicated age } \\
\hline & 60 & 61 & 62 & 63 & 64 & 65 & 66 & 67 & 68 & 69 & 70 \\
\hline \multicolumn{12}{|c|}{ Full retirement age } \\
\hline 60 & 0.46 & 0.46 & 0.46 & 0.46 & 0.46 & 0.79 & 0.79 & 0.79 & 0.79 & 0.79 & 0.79 \\
\hline 61 & - & 0.49 & 0.49 & 0.49 & 0.49 & 0.83 & 0.83 & 0.83 & 0.83 & 0.83 & 0.83 \\
\hline 62 & - & - & 0.53 & 0.53 & 0.53 & 0.87 & 0.87 & 0.87 & 0.87 & 0.87 & 0.87 \\
\hline 63 & - & - & - & 0.57 & 0.57 & 0.91 & 0.91 & 0.91 & 0.91 & 0.91 & 0.91 \\
\hline \multicolumn{12}{|c|}{ Partial retirement age } \\
\hline $60(5 \mathrm{yrs})$ & $0.78^{*}$ & $0.78^{*}$ & $0.80 *$ & $0.80^{*}$ & $0.81 *$ & 0.91 & 0.91 & 0.91 & 0.91 & 0.91 & 0.91 \\
\hline 61 (4 yrs) & - & $0.80^{*}$ & $0.81 *$ & $0.82 *$ & $0.83 *$ & 0.92 & 0.92 & 0.92 & 0.92 & 0.92 & 0.92 \\
\hline 62 (3 yrs) & - & - & $0.83 *$ & $0.83 *$ & $0.84 *$ & 0.94 & 0.94 & 0.94 & 0.94 & 0.94 & 0.94 \\
\hline 63 (2 yrs) & - & - & - & $0.85^{*}$ & $0.86^{*}$ & 0.97 & 0.97 & 0.97 & 0.97 & 0.97 & 0.97 \\
\hline
\end{tabular}

Notes: The replacement rates with an asterisk $(*)$ represent those during partial retirement. The table assumes that the employee trades off occupational pension rights.

selected gradual retirement scenarios ${ }^{37}$ where the employee retires before age 65 and claims occupational pension rights that are 20 per cent higher than what he would normally get (baseline scenario in Table 6). Consequently, his pension rights are reduced as of age 65 by an amount depending on the age when additional pension rights are claimed (with respect to the age-dependent actuarial factors derived from Table 2). The employee cannot claim more pension rights than the amounts given in the table, due to the fiscal constraints described in the section "An occupational pension scheme".

Comparing the replacement rates in the upper panels of Tables 6 and 8 shows that replacement rates increase by about 7 percentage points before age 65 and fall by about 2 percentage points as of age 65 when additional pension rights are claimed before age 65 . Note that pension rights are actuarially reduced due to early claiming that restricts the increase in the replacement rates before age 65 .

The lower panels in Tables 6 and 8 show that the increase in the replacement rates during partial retirement is lower than that at the same ages during full retirement. This is because only the partial occupational pension rights claimed during partial retirement are increased according to the trade-off. These results show that employees benefit from trading off their occupational pension rights since they can smooth their income path. However, the difference between the replacement rates in the case of full retirement before and after age 65 in Table 8 is still substantial. This suggests that the fiscal law that restricts the amount of the pension rights that can be traded off against future rights can be loosened for employees that meet a certain number of years of contribution so that they can better smooth their income path and still achieve a certain replacement rate at age 65 .

${ }^{37}$ Table 8 does not consider retirement scenarios where the employee retires at or after age 65 , since the employee receives the state pension by then and income smoothing is no longer necessary. Moreover, we only selected gradual retirement scenarios where gradual retirement ends at age 65 , when the state pension kicks in. These scenarios are probably the most relevant ones, as individuals might be less inclined to work part-time once they are entitled to the state pension. 
Table 9 Net replacement rates when the work income is $€ 15,000$

\begin{tabular}{|c|c|c|c|c|c|c|c|c|c|c|c|}
\hline & \multicolumn{11}{|c|}{ Replacement rate at the indicated age } \\
\hline & 60 & 61 & 62 & 63 & 64 & 65 & 66 & 67 & 68 & 69 & 70 \\
\hline \multicolumn{12}{|c|}{ Full retirement age } \\
\hline 60 & 0.25 & 0.25 & 0.25 & 0.25 & 0.25 & 0.94 & 0.94 & 0.94 & 0.94 & 0.94 & 0.94 \\
\hline 61 & - & 0.28 & 0.28 & 0.28 & 0.28 & 0.96 & 0.96 & 0.96 & 0.96 & 0.96 & 0.96 \\
\hline 62 & - & - & 0.30 & 0.30 & 0.30 & 0.98 & 0.98 & 0.98 & 0.98 & 0.98 & 0.98 \\
\hline 63 & - & - & - & 0.33 & 0.33 & 1.01 & 1.01 & 1.01 & 1.01 & 1.01 & 1.01 \\
\hline 64 & - & - & - & - & 0.37 & 1.03 & 1.03 & 1.03 & 1.03 & 1.03 & 1.03 \\
\hline 65 & - & - & - & - & - & 1.06 & 1.06 & 1.06 & 1.06 & 1.06 & 1.06 \\
\hline 66 & - & - & - & - & - & - & 1.13 & 1.13 & 1.13 & 1.13 & 1.13 \\
\hline 67 & - & - & - & - & - & - & - & 1.20 & 1.20 & 1.20 & 1.20 \\
\hline 68 & - & - & - & - & - & - & - & - & 1.28 & 1.28 & 1.28 \\
\hline 69 & - & - & - & - & - & - & - & - & - & 1.37 & 1.37 \\
\hline 70 & - & - & - & - & - & - & - & - & - & - & 1.46 \\
\hline \multicolumn{12}{|c|}{ Partial retirement age } \\
\hline $60(5 \mathrm{yrs})$ & $0.64 *$ & $0.64 *$ & $0.64 *$ & $0.64 *$ & $0.64 *$ & 1.00 & 1.00 & 1.00 & 1.00 & 1.00 & 1.00 \\
\hline 61 & - & $0.65^{*}$ & $0.65^{*}$ & $0.65^{*}$ & $0.65^{*}$ & $1.09 *$ & 1.05 & 1.05 & 1.05 & 1.05 & 1.05 \\
\hline 62 & - & - & $0.66^{*}$ & $0.66^{*}$ & $0.66^{*}$ & $1.10 *$ & $1.10 *$ & 1.09 & 1.09 & 1.09 & 1.09 \\
\hline 63 & - & - & - & $0.67 *$ & $0.67 *$ & $1.12 *$ & $1.12 *$ & $1.12 *$ & 1.15 & 1.15 & 1.15 \\
\hline 64 & - & - & - & - & $0.69 *$ & $1.13^{*}$ & $1.13 *$ & $1.13^{*}$ & $1.13^{*}$ & 1.20 & 1.20 \\
\hline 65 & - & - & - & - & - & $1.15^{*}$ & $1.15^{*}$ & $1.15^{*}$ & $1.15^{*}$ & $1.15^{*}$ & 1.27 \\
\hline 61 (4 yrs) & - & $0.65^{*}$ & $0.65^{*}$ & $0.65 *$ & $0.65 *$ & 1.01 & 1.01 & 1.01 & 1.01 & 1.01 & 1.01 \\
\hline 62 & - & - & $0.66^{*}$ & $0.66^{*}$ & $0.66^{*}$ & $1.10^{*}$ & 1.06 & 1.06 & 1.06 & 1.06 & 1.06 \\
\hline 63 & - & - & - & $0.67 *$ & $0.67 *$ & $1.12 *$ & $1.12 *$ & 1.10 & 1.10 & 1.10 & 1.10 \\
\hline 64 & - & - & - & - & $0.69 *$ & $1.13^{*}$ & $1.13^{*}$ & $1.13^{*}$ & 1.16 & 1.16 & 1.16 \\
\hline 65 & - & - & - & - & - & $1.15^{*}$ & $1.15^{*}$ & $1.15^{*}$ & $1.15^{*}$ & 1.22 & 1.22 \\
\hline 62 (3 yrs) & - & - & $0.66^{*}$ & $0.66^{*}$ & $0.66^{*}$ & 1.02 & 1.02 & 1.02 & 1.02 & 1.02 & 1.02 \\
\hline 63 & - & - & - & $0.67 *$ & $0.67 *$ & $1.12 *$ & 1.07 & 1.07 & 1.07 & 1.07 & 1.07 \\
\hline 64 & - & - & - & - & $0.69 *$ & $1.13^{*}$ & $1.13^{*}$ & 1.12 & 1.12 & 1.12 & 1.12 \\
\hline 65 & - & - & - & - & - & $1.15^{*}$ & $1.15^{*}$ & $1.15^{*}$ & 1.17 & 1.17 & 1.17 \\
\hline 63 (2 yrs) & - & - & - & $0.67 *$ & $0.67 *$ & 1.07 & 1.07 & 1.07 & 1.07 & 1.07 & 1.07 \\
\hline 64 & - & - & - & - & $0.69 *$ & $1.13^{*}$ & 1.08 & 1.08 & 1.08 & 1.08 & 1.08 \\
\hline 65 & - & - & - & - & - & $1.15^{*}$ & $1.15^{*}$ & 1.13 & 1.13 & 1.13 & 1.13 \\
\hline
\end{tabular}

Notes: The replacement rates with an asterisk (*) represent those during partial retirement. The table assumes that the work income is $€ 15,000$.

\section{Different earnings levels}

In our baseline analysis in Table 6, we assumed that the employee earns a gross income of $€ 30,000$ a year, which is roughly the average gross wage in the Netherlands. In this subsection, we consider two alternative levels of work income: a low-income level of $€ 15,000$, which is roughly the gross minimum wage in the Netherlands, and a highincome level of $€ 60,000$. Tables 9 and 10 present the net replacement rates for these incomes. 
Table 10 Net replacement rates when the work income is $€ 60,000$

\begin{tabular}{|c|c|c|c|c|c|c|c|c|c|c|c|}
\hline & \multicolumn{11}{|c|}{ Replacement rate at the indicated age } \\
\hline & 60 & 61 & 62 & 63 & 64 & 65 & 66 & 67 & 68 & 69 & 70 \\
\hline \multicolumn{12}{|c|}{ Full retirement age } \\
\hline 60 & 0.47 & 0.47 & 0.47 & 0.47 & 0.47 & 0.74 & 0.74 & 0.74 & 0.74 & 0.74 & 0.74 \\
\hline 61 & - & 0.50 & 0.50 & 0.50 & 0.50 & 0.77 & 0.77 & 0.77 & 0.77 & 0.77 & 0.77 \\
\hline 62 & - & - & 0.54 & 0.54 & 0.54 & 0.83 & 0.83 & 0.83 & 0.83 & 0.83 & 0.83 \\
\hline 63 & - & - & - & 0.58 & 0.58 & 0.89 & 0.89 & 0.89 & 0.89 & 0.89 & 0.89 \\
\hline 64 & - & - & - & - & 0.61 & 0.96 & 0.96 & 0.96 & 0.96 & 0.96 & 0.96 \\
\hline 65 & - & - & - & - & - & 1.04 & 1.04 & 1.04 & 1.04 & 1.04 & 1.04 \\
\hline 66 & - & - & - & - & - & - & 1.14 & 1.14 & 1.14 & 1.14 & 1.14 \\
\hline 67 & - & - & - & - & - & - & - & 1.26 & 1.26 & 1.26 & 1.26 \\
\hline 68 & - & - & - & - & - & - & - & - & 1.38 & 1.38 & 1.38 \\
\hline 69 & - & - & - & - & - & - & - & - & - & 1.53 & 1.53 \\
\hline 70 & - & - & - & - & - & - & - & - & - & - & 1.56 \\
\hline \multicolumn{12}{|c|}{ Partial retirement age } \\
\hline $60(5 \mathrm{yrs})$ & $0.73 *$ & $0.73 *$ & $0.76^{*}$ & $0.77 *$ & $0.79 *$ & 0.88 & 0.88 & 0.88 & 0.88 & 0.88 & 0.88 \\
\hline 61 & - & $0.75^{*}$ & $0.78^{*}$ & $0.79 *$ & $0.81 *$ & $1.04 *$ & 0.95 & 0.95 & 0.95 & 0.95 & 0.95 \\
\hline 62 & - & - & $0.80^{*}$ & $0.81 *$ & $0.83 *$ & $1.07 *$ & $1.07 *$ & 1.04 & 1.04 & 1.04 & 1.04 \\
\hline 63 & - & - & - & $0.83^{*}$ & $0.85^{*}$ & $1.10^{*}$ & $1.10 *$ & $1.09^{*}$ & 1.14 & 1.14 & 1.14 \\
\hline 64 & - & - & - & - & $0.88 *$ & $1.13^{*}$ & $1.13 *$ & $1.13^{*}$ & $1.13^{*}$ & 1.24 & 1.24 \\
\hline 65 & - & - & - & - & - & $1.17^{*}$ & $1.17 *$ & $1.16^{*}$ & $1.16^{*}$ & $1.16^{*}$ & 1.36 \\
\hline 61 (4 yrs) & - & $0.75^{*}$ & $0.78^{*}$ & $0.79 *$ & $0.81 *$ & 0.90 & 0.90 & 0.90 & 0.90 & 0.90 & 0.90 \\
\hline 62 & - & - & $0.80^{*}$ & $0.81 *$ & $0.83 *$ & $1.07 *$ & 0.98 & 0.98 & 0.98 & 0.98 & 0.98 \\
\hline 63 & - & - & - & $0.83^{*}$ & $0.85^{*}$ & $1.10^{*}$ & $1.10 *$ & 1.07 & 1.07 & 1.07 & 1.07 \\
\hline 64 & - & - & - & - & $0.88 *$ & $1.13^{*}$ & $1.13 *$ & $1.13^{*}$ & 1.17 & 1.17 & 1.17 \\
\hline 65 & - & - & - & - & - & $1.17^{*}$ & $1.17^{*}$ & $1.16^{*}$ & $1.16^{*}$ & 1.28 & 1.28 \\
\hline 62 (3 yrs) & - & - & $0.80 *$ & $0.81 *$ & $0.83 *$ & 0.93 & 0.93 & 0.93 & 0.93 & 0.93 & 0.93 \\
\hline 63 & - & - & - & $0.83^{*}$ & $0.85^{*}$ & $1.10 *$ & 1.02 & 1.02 & 1.02 & 1.02 & 1.02 \\
\hline 64 & - & - & - & - & $0.88 *$ & $1.13^{*}$ & $1.13 *$ & 1.11 & 1.11 & 1.11 & 1.11 \\
\hline 65 & - & - & - & - & - & $1.17 *$ & $1.17 *$ & $1.16^{*}$ & 1.21 & 1.21 & 1.21 \\
\hline 63 (2 yrs) & - & - & - & $0.83^{*}$ & $0.85^{*}$ & 0.97 & 0.97 & 0.97 & 0.97 & 0.97 & 0.97 \\
\hline 64 & - & - & - & - & $0.88 *$ & $1.13^{*}$ & 1.05 & 1.05 & 1.05 & 1.05 & 1.05 \\
\hline 65 & - & - & - & - & - & $1.17 *$ & $1.17 *$ & 1.15 & 1.15 & 1.15 & 1.15 \\
\hline
\end{tabular}

Notes: The replacement rates with an asterisk $(*)$ represent those during partial retirement. The table assumes that the work income is $€ 60,000$.

The comparison of the replacement rates reveals the following results. First, in the case of early abrupt retirement, when the retirement income consists of only the occupational pension, low-income earners realise a lower replacement rate before age 65 . This is because low-income earners accumulate less occupational pension rights relative to their work income. In particular, as work income decreases, the $P B$ (defined by Eq. (2)) decreases at a higher pace, since the $S P O$ is fixed. Moreover, the replacement rates are lower for the lowest income earners, because the amount of the tax they pay is so low that they cannot fully benefit 
from the flat-rate general tax credit (see the section "The Dutch tax system"). Second, in the case of early retirement, low-income earners realise a higher replacement rate as of age 65 , whereas in the case of late retirement, they realise a lower replacement rate after age 65 than the high-income earners. The gap between the replacement rates across the income groups narrows around age 65 . The reason for this pattern is that, for low-income earners, the share of the occupational pension in the replacement rate is lower than that of the state pension, so that by retiring later, they accumulate less occupational pension rights relative to their work income.

Comparing the replacement rates for gradual retirement shows that, first, the difference between the replacement rates across income groups during the years of partial retirement is smaller than that during the corresponding years of full retirement in the upper panels of the tables. This is because during partial retirement, the replacement rate also accounts for income from work and therefore changes closer to proportionally with work income. Second, the difference between the replacement rates across the income groups during the years of full retirement following partial retirement is also smaller than that during the corresponding years of full retirement in the upper panel. This is because during partial retirement employees accumulate occupational pension rights which in turn increase the replacement rate during full retirement, but the replacement rate for high-income earners increases more than that for lowincome earners, reducing the difference between the replacement rates of the two income groups. These results therefore imply that, in the case of gradual retirement, there is less variation in the replacement rates across the income groups than in the case of full retirement.

Table 11 combines the analysis of different pre-retirement earnings levels with the opportunities to smooth income discussed in the previous subsection. The top panel reproduces Table 8, for the reader's convenience. The other two panels exploit the pension trade-off possibilities to their maximum extent for the low- and high-income levels considered above. For the low-income group, the occupational pension is small compared with the state pension, implying that opportunities for income smoothing through the occupational pension are very limited, particularly in the case of gradual retirement. For the high-income groups, the induced flexibility is much larger, both for abrupt and gradual retirement. Trading off occupational pension rights makes it possible to reduce the gap between pre- and post state pension eligibility to less than 10 percentage points.

The preceding analysis allows for different levels of work income and analyses the corresponding changes in the replacement rates, but it maintains the assumption that gross work income is constant over time. In reality, however, the age profile of work income is usually upward sloping over the life cycle. ${ }^{38}$ In our analysis, work income affects the value of a replacement rate through the pension wealth in the numerator of the replacement rate, and through the average lifetime work income in the denominator. This means that an alternative income profile specification could have several effects on the replacement rates and it is not a priori clear which effect dominates. Still, Knoef et al. ${ }^{39}$ show that the ageincome profiles in the Netherlands are rather flat as of age 60. This suggests that the accrual of pension rights in the age range we consider (60 is the earliest retirement age in our scenarios) can be approximated reasonably well with a constant earnings profile. As a

\footnotetext{
38 See, e.g. Murphy and Welch (1990).

${ }^{39}$ Knoef et al. (2009).
} 
Table 11 Net replacement rates when pension rights are traded off against future rights under alternative levels of work income

\begin{tabular}{|c|c|c|c|c|c|c|c|c|c|c|c|}
\hline & \multicolumn{11}{|c|}{ Replacement rate at the indicated age } \\
\hline & 60 & 61 & 62 & 63 & 64 & 65 & 66 & 67 & 68 & 69 & 70 \\
\hline \multicolumn{12}{|c|}{ Work income: 30,000} \\
\hline \multicolumn{12}{|c|}{ Full retirement age } \\
\hline 60 & 0.46 & 0.46 & 0.46 & 0.46 & 0.46 & 0.79 & 0.79 & 0.79 & 0.79 & 0.79 & 0.79 \\
\hline 61 & - & 0.49 & 0.49 & 0.49 & 0.49 & 0.83 & 0.83 & 0.83 & 0.83 & 0.83 & 0.83 \\
\hline 62 & - & - & 0.53 & 0.53 & 0.53 & 0.87 & 0.87 & 0.87 & 0.87 & 0.87 & 0.87 \\
\hline 63 & - & - & - & 0.57 & 0.57 & 0.91 & 0.91 & 0.91 & 0.91 & 0.91 & 0.91 \\
\hline \multicolumn{12}{|c|}{ Partial retirement age } \\
\hline $60(5 \mathrm{yrs})$ & $0.78 *$ & $0.78^{*}$ & $0.80 *$ & $0.80 *$ & $0.81 *$ & 0.91 & 0.91 & 0.91 & 0.91 & 0.91 & 0.91 \\
\hline 61 (4 yrs) & - & $0.80^{*}$ & $0.81 *$ & $0.82 *$ & $0.83 *$ & 0.92 & 0.92 & 0.92 & 0.92 & 0.92 & 0.92 \\
\hline $62(3 \mathrm{yrs})$ & - & - & $0.83^{*}$ & $0.83^{*}$ & $0.84 *$ & 0.94 & 0.94 & 0.94 & 0.94 & 0.94 & 0.94 \\
\hline 63 (2 yrs) & - & - & - & $0.85^{*}$ & $0.86^{*}$ & 0.97 & 0.97 & 0.97 & 0.97 & 0.97 & 0.97 \\
\hline \multicolumn{12}{|c|}{ Work income: 15,000} \\
\hline \multicolumn{12}{|c|}{ Full retirement age } \\
\hline 60 & 0.31 & 0.31 & 0.31 & 0.31 & 0.31 & 0.93 & 0.93 & 0.93 & 0.93 & 0.93 & 0.93 \\
\hline 61 & - & 0.33 & 0.33 & 0.33 & 0.33 & 0.95 & 0.95 & 0.95 & 0.95 & 0.95 & 0.95 \\
\hline 62 & - & - & 0.37 & 0.37 & 0.37 & 0.97 & 0.97 & 0.97 & 0.97 & 0.97 & 0.97 \\
\hline 63 & - & - & - & 0.40 & 0.40 & 1.00 & 1.00 & 1.00 & 1.00 & 1.00 & 1.00 \\
\hline \multicolumn{12}{|c|}{ Partial retirement age } \\
\hline $60(5 \mathrm{yrs})$ & $0.66^{*}$ & $0.66^{*}$ & $0.66^{*}$ & $0.66^{*}$ & $0.66^{*}$ & 0.99 & 0.99 & 0.99 & 0.99 & 0.99 & 0.99 \\
\hline $61(4 \mathrm{yrs})$ & - & $0.67 *$ & $0.67 *$ & $0.67 *$ & $0.67 *$ & 1.01 & 1.01 & 1.01 & 1.01 & 1.01 & 1.01 \\
\hline $62(3 \mathrm{yrs})$ & - & - & $0.69 *$ & $0.69^{*}$ & $0.69 *$ & 1.02 & 1.02 & 1.02 & 1.02 & 1.02 & 1.02 \\
\hline $63(2 \mathrm{yrs})$ & - & - & - & $0.70^{*}$ & $0.70 *$ & 1.06 & 1.06 & 1.06 & 1.06 & 1.06 & 1.06 \\
\hline \multicolumn{12}{|c|}{ Work income: 60,000} \\
\hline \multicolumn{12}{|c|}{ Full retirement age } \\
\hline 60 & 0.54 & 0.54 & 0.54 & 0.54 & 0.54 & 0.73 & 0.73 & 0.73 & 0.73 & 0.73 & 0.73 \\
\hline 61 & - & 0.58 & 0.58 & 0.58 & 0.58 & 0.74 & 0.74 & 0.74 & 0.74 & 0.74 & 0.74 \\
\hline 62 & - & - & 0.61 & 0.61 & 0.61 & 0.80 & 0.80 & 0.80 & 0.80 & 0.80 & 0.80 \\
\hline 63 & - & - & - & 0.67 & 0.67 & 0.87 & 0.87 & 0.87 & 0.87 & 0.87 & 0.87 \\
\hline \multicolumn{12}{|c|}{ Partial retirement age } \\
\hline $60(5 \mathrm{yrs})$ & $0.77 *$ & $0.77 *$ & $0.80 *$ & $0.81 *$ & $0.83^{*}$ & 0.86 & 0.86 & 0.86 & 0.86 & 0.86 & 0.86 \\
\hline 61 (4 yrs) & - & $0.79 *$ & $0.82 *$ & $0.83^{*}$ & $0.85 *$ & 0.89 & 0.89 & 0.89 & 0.89 & 0.89 & 0.89 \\
\hline 62 (3 yrs) & - & - & $0.85^{*}$ & $0.86^{*}$ & $0.88 *$ & 0.92 & 0.92 & 0.92 & 0.92 & 0.92 & 0.92 \\
\hline 63 (2 yrs) & - & - & - & $0.89 *$ & $0.90 *$ & 0.95 & 0.95 & 0.95 & 0.95 & 0.95 & 0.95 \\
\hline
\end{tabular}

Notes: The replacement rates with an asterisk (*) represent those during partial retirement. The table assumes that the employee trades off occupational pension rights.

consequence, our main results concerning the analysis of the relative changes in the replacement rates across different retirement scenarios would remain unaffected, since a change in the income profile would affect the replacement rates in different retirement scenarios to similar extents. For simplicity, we therefore retain our assumption that the income profile is flat over the life cycle. 


\section{Career interruptions and service length}

In our baseline analysis in Table 6, we calculated net replacement rates under the assumption of an uninterrupted service length of 40 years in the case of retirement at age 65. In practice, many people have periods out of the labour force and contribute much less to an occupational pension fund (see also the section "The Dutch pension and income tax systems"). For employees with career gaps, 40 years of occupational pension contributions is unrealistic, and we therefore consider a service length of 20 years at age 65 in Table $12 .{ }^{40}$ These results can also be extrapolated to other changes in service length.

The comparison of the replacement rates in the upper panels of Tables 12 and 6 reveals, as expected, that the replacement rates are lower when the service length is shorter, because employees accumulate less occupational pension rights (see Eq. (2)). Still, the employee achieves a net replacement rate of 74 per cent at age 65 . Second, the difference between the replacement rates increases as the retirement age increases. This is because those with a shorter service length accumulate less occupational pension rights with smaller actuarial increases on these rights. The shorter the service length, the larger the weight of the state pension, with its lower actuarial rewards for later claiming.

The main result from the comparison of the replacement rates in the lower panels of Tables 12 and 6 is that the difference between the replacement rates across the two groups of service length during the years of partial retirement is smaller than that during the corresponding years of full retirement in the upper panels of the tables. This is because, in the case of partial retirement, the retirement income includes work income and therefore depends less on the occupational pension income.

\section{Domestic situation}

The amounts of the occupational pension, the state pension, the flat rate health insurance premium and certain tax credits depend on the domestic situation, as explained in the sections "An occupational pension scheme", "The state pension scheme" and "The Dutch tax system". In our baseline analysis in Table 6, we calculated the net replacement rates under the assumption that the employee is not single. However, a substantial fraction, 30 per cent, of the pensioners in the Netherlands are single at age $65 .{ }^{41}$ Table 13 presents the replacement rates when the employee is single (and has no children living with him). ${ }^{42}$

The comparison of the replacement rates in the upper panels of the tables reveals the following results. First, before age 65, the replacement rates are about 3 percentage points higher if the employee is single. This is because the accumulated occupational pension rights are increased if the employee is single by the time he claims his pension rights (see the section "An occupational pension scheme"), but also because he pays a lower flat rate health insurance premium and receives the elderly single person's tax credit. As of age 65, the

\footnotetext{
40 According to survey data from the DNB Household Survey 2010, the average length of service of participants of ages 60 and older in the pension fund considered is about 30 years. The mode is 40 years.

41 van Sonsbeek (2010).

${ }^{42}$ If the employee is divorced, it is assumed that the arrangement with the spouse is such that she (has her own pension and) is not entitled to part of the employee's pension.
} 
Table 12 Net replacement rates when the service length is 20 years

\begin{tabular}{|c|c|c|c|c|c|c|c|c|c|c|c|}
\hline & \multicolumn{11}{|c|}{ Replacement rate at the indicated age } \\
\hline & 60 & 61 & 62 & 63 & 64 & 65 & 66 & 67 & 68 & 69 & 70 \\
\hline \multicolumn{12}{|c|}{ Full retirement age } \\
\hline 60 & 0.20 & 0.20 & 0.20 & 0.20 & 0.20 & 0.60 & 0.60 & 0.60 & 0.60 & 0.60 & 0.60 \\
\hline 61 & - & 0.23 & 0.23 & 0.23 & 0.23 & 0.63 & 0.63 & 0.63 & 0.63 & 0.63 & 0.63 \\
\hline 62 & - & - & 0.26 & 0.26 & 0.26 & 0.65 & 0.65 & 0.65 & 0.65 & 0.65 & 0.65 \\
\hline 63 & - & - & - & 0.29 & 0.29 & 0.68 & 0.68 & 0.68 & 0.68 & 0.68 & 0.68 \\
\hline 64 & - & - & - & - & 0.31 & 0.71 & 0.71 & 0.71 & 0.71 & 0.71 & 0.71 \\
\hline 65 & - & - & - & - & - & 0.74 & 0.74 & 0.74 & 0.74 & 0.74 & 0.74 \\
\hline 66 & - & - & - & - & - & - & 0.80 & 0.80 & 0.80 & 0.80 & 0.80 \\
\hline 67 & - & - & - & - & - & - & - & 0.86 & 0.86 & 0.86 & 0.86 \\
\hline 68 & - & - & - & - & - & - & - & - & 0.92 & 0.92 & 0.92 \\
\hline 69 & - & - & - & - & - & - & - & - & - & 0.99 & 0.99 \\
\hline 70 & - & - & - & - & - & - & - & - & - & - & 1.08 \\
\hline \multicolumn{12}{|c|}{ Partial retirement age } \\
\hline $60(5 \mathrm{yrs})$ & $0.66^{*}$ & $0.66^{*}$ & $0.68 *$ & $0.68 *$ & $0.69 *$ & 0.67 & 0.67 & 0.67 & 0.67 & 0.67 & 0.67 \\
\hline 61 & - & $0.67 *$ & $0.69 *$ & $0.69 *$ & $0.70 *$ & $0.98^{*}$ & 0.71 & 0.71 & 0.71 & 0.71 & 0.71 \\
\hline 62 & - & - & $0.70^{*}$ & $0.70 *$ & $0.71 *$ & $0.99 *$ & $0.99 *$ & 0.76 & 0.76 & 0.76 & 0.76 \\
\hline 63 & - & - & - & $0.72 *$ & $0.73 *$ & $1.00 *$ & $1.00 *$ & $1.00 *$ & 0.81 & 0.81 & 0.81 \\
\hline 64 & - & - & - & - & $0.74 *$ & $1.01 *$ & $1.01 *$ & $1.01 *$ & $1.01 *$ & 0.86 & 0.86 \\
\hline 65 & - & - & - & - & - & $1.03^{*}$ & $1.03 *$ & $1.03 *$ & $1.03 *$ & $1.03 *$ & 0.91 \\
\hline 61 (4 yrs) & - & $0.67 *$ & $0.69 *$ & $0.69 *$ & $0.70 *$ & 0.68 & 0.68 & 0.68 & 0.68 & 0.68 & 0.68 \\
\hline 62 & - & - & $0.70^{*}$ & $0.70 *$ & $0.71 *$ & $0.99 *$ & 0.73 & 0.73 & 0.73 & 0.73 & 0.73 \\
\hline 63 & - & - & - & $0.72 *$ & $0.73 *$ & $1.00^{*}$ & $1.00 *$ & 0.77 & 0.77 & 0.77 & 0.77 \\
\hline 64 & - & - & - & - & $0.74 *$ & $1.01 *$ & $1.01 *$ & $1.01 *$ & 0.82 & 0.82 & 0.82 \\
\hline 65 & - & - & - & - & - & $1.03^{*}$ & $1.03 *$ & $1.03 *$ & $1.03 *$ & 0.87 & 0.87 \\
\hline 62 (3 yrs) & - & - & $0.70 *$ & $0.70 *$ & $0.71 *$ & 0.70 & 0.70 & 0.70 & 0.70 & 0.70 & 0.70 \\
\hline 63 & - & - & - & $0.72 *$ & $0.73 *$ & $1.00 *$ & 0.74 & 0.74 & 0.74 & 0.74 & 0.74 \\
\hline 64 & - & - & - & - & $0.74 *$ & $1.01^{*}$ & $1.01 *$ & 0.79 & 0.79 & 0.79 & 0.79 \\
\hline 65 & - & - & - & - & - & $1.03 *$ & $1.03 *$ & $1.03 *$ & 0.84 & 0.84 & 0.84 \\
\hline 63 (2 yrs) & - & - & - & $0.72 *$ & $0.73 *$ & 0.72 & 0.72 & 0.72 & 0.72 & 0.72 & 0.72 \\
\hline 64 & - & - & - & - & $0.74 *$ & $1.01 *$ & 0.76 & 0.76 & 0.76 & 0.76 & 0.76 \\
\hline 65 & - & - & - & - & - & $1.03^{*}$ & $1.03 *$ & 0.80 & 0.80 & 0.80 & 0.80 \\
\hline
\end{tabular}

Notes: The replacement rates with an asterisk (*) represent those during partial retirement. The table assumes that the service length is 20 years.

replacement rates are about 20 percentage points higher if the employee is single. The additional increase is due to the fact that the single beneficiary receives an increased state pension as of age 65 (see the section "The state pension scheme"). The comparison of the replacement rates in the lower panels of the tables shows that the difference between the replacement rates across the two domestic situations during the years of partial retirement is smaller than that during the corresponding years of full retirement in the upper panels of the tables. This is because the employee claims only part of his accrued pension rights 
Table 13 Net replacement rates when the employee is single

\begin{tabular}{|c|c|c|c|c|c|c|c|c|c|c|c|}
\hline & \multicolumn{11}{|c|}{ Replacement rate at the indicated age } \\
\hline & 60 & 61 & 62 & 63 & 64 & 65 & 66 & 67 & 68 & 69 & 70 \\
\hline \multicolumn{12}{|c|}{ Full retirement age } \\
\hline 60 & 0.43 & 0.43 & 0.43 & 0.43 & 0.43 & 1.00 & 1.00 & 1.00 & 1.00 & 1.00 & 1.00 \\
\hline 61 & - & 0.46 & 0.46 & 0.46 & 0.46 & 1.03 & 1.03 & 1.03 & 1.03 & 1.03 & 1.03 \\
\hline 62 & - & - & 0.49 & 0.49 & 0.49 & 1.07 & 1.07 & 1.07 & 1.07 & 1.07 & 1.07 \\
\hline 63 & - & - & - & 0.52 & 0.52 & 1.11 & 1.11 & 1.11 & 1.11 & 1.11 & 1.11 \\
\hline 64 & - & - & - & - & 0.56 & 1.15 & 1.15 & 1.15 & 1.15 & 1.15 & 1.15 \\
\hline 65 & - & - & - & - & - & 1.20 & 1.20 & 1.20 & 1.20 & 1.20 & 1.20 \\
\hline 66 & - & - & - & - & - & - & 1.28 & 1.28 & 1.28 & 1.28 & 1.28 \\
\hline 67 & - & - & - & - & - & - & - & 1.37 & 1.37 & 1.37 & 1.37 \\
\hline 68 & - & - & - & - & - & - & - & - & 1.45 & 1.45 & 1.45 \\
\hline 69 & - & - & - & - & - & - & - & - & - & 1.57 & 1.57 \\
\hline 70 & - & - & - & - & - & - & - & - & - & - & 1.71 \\
\hline \multicolumn{12}{|c|}{ Partial retirement age } \\
\hline $60(5 \mathrm{yrs})$ & $0.77 *$ & $0.77 *$ & $0.79 *$ & $0.79 *$ & $0.80^{*}$ & 1.10 & 1.10 & 1.10 & 1.10 & 1.10 & 1.10 \\
\hline 61 & - & $0.78^{*}$ & $0.80^{*}$ & $0.80^{*}$ & $0.81 *$ & $1.18^{*}$ & 1.16 & 1.16 & 1.16 & 1.16 & 1.16 \\
\hline 62 & - & - & $0.81 *$ & $0.82 *$ & $0.83 *$ & $1.20^{*}$ & $1.20 *$ & 1.22 & 1.22 & 1.22 & 1.22 \\
\hline 63 & - & - & - & $0.83^{*}$ & $0.84 *$ & $1.22 *$ & $1.22 *$ & $1.21 *$ & 1.29 & 1.29 & 1.29 \\
\hline 64 & - & - & - & - & $0.86^{*}$ & $1.24 *$ & $1.24 *$ & $1.24 *$ & $1.24 *$ & 1.37 & 1.37 \\
\hline 65 & - & - & - & - & - & $1.26^{*}$ & $1.26^{*}$ & $1.26^{*}$ & $1.26^{*}$ & $1.26^{*}$ & 1.43 \\
\hline 61 (4 yrs) & - & $0.78^{*}$ & $0.80 *$ & $0.80^{*}$ & $0.81 *$ & 1.12 & 1.12 & 1.12 & 1.12 & 1.12 & 1.12 \\
\hline 62 & - & - & $0.81 *$ & $0.82 *$ & $0.83 *$ & $1.20^{*}$ & 1.18 & 1.18 & 1.18 & 1.18 & 1.18 \\
\hline 63 & - & - & - & $0.83^{*}$ & $0.84^{*}$ & $1.22 *$ & $1.22 *$ & 1.24 & 1.24 & 1.24 & 1.24 \\
\hline 64 & - & - & - & - & $0.86^{*}$ & $1.24 *$ & $1.24 *$ & $1.24^{*}$ & 1.31 & 1.31 & 1.31 \\
\hline 65 & - & - & - & - & - & $1.26^{*}$ & $1.26^{*}$ & $1.26^{*}$ & $1.26^{*}$ & 1.36 & 1.36 \\
\hline 62 (3 yrs) & - & - & $0.81^{*}$ & $0.82 *$ & $0.83^{*}$ & 1.14 & 1.14 & 1.14 & 1.14 & 1.14 & 1.14 \\
\hline 63 & - & - & - & $0.83^{*}$ & $0.84 *$ & $1.22 *$ & 1.20 & 1.20 & 1.20 & 1.20 & 1.20 \\
\hline 64 & - & - & - & - & $0.86^{*}$ & $1.24 *$ & $1.24 *$ & 1.26 & 1.26 & 1.26 & 1.26 \\
\hline 65 & - & - & - & - & - & $1.26^{*}$ & $1.26^{*}$ & $1.26^{*}$ & 1.34 & 1.34 & 1.34 \\
\hline 63 (2 yrs) & - & - & - & $0.83^{*}$ & $0.84 *$ & 1.16 & 1.16 & 1.16 & 1.16 & 1.16 & 1.16 \\
\hline 64 & - & - & - & - & $0.86^{*}$ & $1.24 *$ & 1.22 & 1.22 & 1.22 & 1.22 & 1.22 \\
\hline 65 & - & - & - & - & - & $1.26^{*}$ & $1.26^{*}$ & 1.29 & 1.29 & 1.29 & 1.29 \\
\hline
\end{tabular}

Notes: The replacement rates with an asterisk (*) represent those during partial retirement. The table assumes that the domestic situation is single.

during partial retirement, implying that the replacement rates increase at a lower pace. When we assume that the employee is single and has children under the age of 18 living with him, the state pension rights increase further, which further increases the replacement rates in Table 13. The employee then also receives as additional tax credits the single parent's tax credit, single parent's supplementary tax credit and the combination tax credit, but, in fact, these reduce the replacement rates as of age 65 , because the amounts fall at age 65 (see Table 4). 
Table 14 Net replacement rates when the occupational pension accrual rate is 0.0155

\begin{tabular}{|c|c|c|c|c|c|c|c|c|c|c|c|}
\hline & \multicolumn{11}{|c|}{ Replacement rate at the indicated age } \\
\hline & 60 & 61 & 62 & 63 & 64 & 65 & 66 & 67 & 68 & 69 & 70 \\
\hline \multicolumn{12}{|c|}{ Full retirement age } \\
\hline 60 & 0.33 & 0.33 & 0.33 & 0.33 & 0.33 & 0.73 & 0.73 & 0.73 & 0.73 & 0.73 & 0.73 \\
\hline 61 & - & 0.35 & 0.35 & 0.35 & 0.35 & 0.76 & 0.76 & 0.76 & 0.76 & 0.76 & 0.76 \\
\hline 62 & - & - & 0.37 & 0.37 & 0.37 & 0.79 & 0.79 & 0.79 & 0.79 & 0.79 & 0.79 \\
\hline 63 & - & - & - & 0.40 & 0.40 & 0.82 & 0.82 & 0.82 & 0.82 & 0.82 & 0.82 \\
\hline 64 & - & - & - & - & 0.42 & 0.85 & 0.85 & 0.85 & 0.85 & 0.85 & 0.85 \\
\hline 65 & - & - & - & - & - & 0.89 & 0.89 & 0.89 & 0.89 & 0.89 & 0.89 \\
\hline 66 & - & - & - & - & - & - & 0.94 & 0.94 & 0.94 & 0.94 & 0.94 \\
\hline 67 & - & - & - & - & - & - & - & 1.01 & 1.01 & 1.01 & 1.01 \\
\hline 68 & - & - & - & - & - & - & - & - & 1.08 & 1.08 & 1.08 \\
\hline 69 & - & - & - & - & - & - & - & - & - & 1.16 & 1.16 \\
\hline 70 & - & - & - & - & - & - & - & - & - & - & 1.26 \\
\hline \multicolumn{12}{|c|}{ Partial retirement age } \\
\hline $0(5 \mathrm{yrs})$ & $0.72 *$ & $0.72 *$ & $0.73 *$ & $0.74 *$ & $0.75^{*}$ & 0.81 & 0.81 & 0.81 & 0.81 & 0.81 & 0.81 \\
\hline 61 & - & $0.73 *$ & $0.74 *$ & $0.75^{*}$ & $0.76^{*}$ & $1.04 *$ & 0.85 & 0.85 & 0.85 & 0.85 & 0.85 \\
\hline 62 & - & - & $0.76^{*}$ & $0.76^{*}$ & $0.77 *$ & $1.05^{*}$ & $1.05 *$ & 0.90 & 0.90 & 0.90 & 0.90 \\
\hline 63 & - & - & - & $0.78 *$ & $0.78 *$ & $1.06^{*}$ & $1.06^{*}$ & $1.06^{*}$ & 0.95 & 0.95 & 0.95 \\
\hline 64 & - & - & - & - & $0.80 *$ & $1.08 *$ & $1.08 *$ & $1.08^{*}$ & $1.08 *$ & 1.01 & 1.01 \\
\hline 65 & - & - & - & - & - & $1.10^{*}$ & $1.10 *$ & $1.09^{*}$ & $1.09 *$ & $1.09 *$ & 1.07 \\
\hline 61 (4 yrs) & - & $0.73 *$ & $0.74 *$ & $0.75 *$ & $0.76^{*}$ & 0.82 & 0.82 & 0.82 & 0.82 & 0.82 & 0.82 \\
\hline 62 & - & - & $0.76^{*}$ & $0.76^{*}$ & $0.77 *$ & $1.05^{*}$ & 0.87 & 0.87 & 0.87 & 0.87 & 0.87 \\
\hline 63 & - & - & - & $0.78 *$ & $0.78 *$ & $1.06^{*}$ & $1.06^{*}$ & 0.91 & 0.91 & 0.91 & 0.91 \\
\hline 64 & - & - & - & - & $0.80 *$ & $1.08 *$ & $1.08 *$ & $1.08^{*}$ & 0.97 & 0.97 & 0.97 \\
\hline 65 & - & - & - & - & - & $1.10^{*}$ & $1.10^{*}$ & $1.09 *$ & $1.09 *$ & 1.02 & 1.02 \\
\hline 62 (3 yrs) & - & - & $0.76^{*}$ & $0.76^{*}$ & $0.77 *$ & 0.84 & 0.84 & 0.84 & 0.84 & 0.84 & 0.84 \\
\hline 63 & - & - & - & $0.78 *$ & $0.78 *$ & $1.06^{*}$ & 0.88 & 0.88 & 0.88 & 0.88 & 0.88 \\
\hline 64 & - & - & - & - & $0.80 *$ & $1.08 *$ & $1.08 *$ & 0.93 & 0.93 & 0.93 & 0.93 \\
\hline 65 & - & - & - & - & - & $1.10^{*}$ & $1.10 *$ & $1.09 *$ & 0.98 & 0.98 & 0.98 \\
\hline 63 (2 yrs) & - & - & - & $0.78 *$ & $0.78 *$ & 0.85 & 0.85 & 0.85 & 0.85 & 0.85 & 0.85 \\
\hline 64 & - & - & - & - & $0.80 *$ & $1.08 *$ & 0.90 & 0.90 & 0.90 & 0.90 & 0.90 \\
\hline 65 & - & - & - & - & - & $1.10^{*}$ & $1.10 *$ & 0.95 & 0.95 & 0.95 & 0.95 \\
\hline
\end{tabular}

Notes: The replacement rates with an asterisk $(*)$ represent those during partial retirement. The table assumes that the occupational pension accrual rate is 0.0155 .

\section{Accrual rate}

Goudswaard et al. $^{43}$ indicate that two factors contribute to the increasing cost of pension benefits in the Netherlands. The first is that the return on the invested pension premiums

\footnotetext{
${ }^{43}$ Goudswaard et al. (2010).
} 
is decreasing due to the structural decline in the interest rates, and the second is that the number of years retirees are drawing pensions is increasing due to increasing life expectancy. They explain that an increase in the pension premiums paid by the employees or a decrease in the pension accrual rate can reduce the cost of pensions. They claim that there is little room for increasing the pension premiums in the Netherlands and therefore favour reducing the pension accrual rate. In fact, the accrual rate of the occupational pension in the Netherlands is among the highest in OECD countries. ${ }^{44}$ The pension regulation in the Netherlands allows pension funds to decrease the accrual rate while keeping the premiums constant. In Table 14 we show how reducing the accrual rate by about 25 per cent from its current level of 2.05 per cent to 1.55 per cent affects the net replacement rates.

The comparison of the replacement rates in the upper panels of Tables 14 and 6 shows that, when the accrual rate is reduced, the net replacement rates fall, for example, by 13 percentage points in the case of full retirement at age 65. This implies that the employee needs to work about two additional years, until age 67, to reach the baseline level of replacement rate. This decrease in the accrual rate, which can be offset by working until age 67, seems to accord well with the government's plans launched in 2009 to increase the retirement age to 67 by 2025 . Note however that our calculation assumes that the state pension is deferred according to the proposed state pension scheme. When we repeat our calculation under the assumption that the state pension is not deferred, the additional number of years of work required to offset the decrease in the accrual rate increases to almost three years. The table shows that the offsetting number of years of work also increases with retirement at earlier ages, since the rate of the actuarial increase in the pension rights for delaying retirement is lower at those ages. In the case of partial retirement, during the partial retirement years, the decrease in the replacement rates is lower, because the replacement rate is proportional to the earned income, but in the years of full retirement, the reduction is about the same as in the case of full retirement.

\section{Conclusion}

Changing life course patterns over the past decades suggest an increasing demand for flexible and individualised pensions, enabling workers to choose their own preferred retirement scenario with fair trade-offs between working longer or a lower pension. In this paper, we have studied the trade-offs in the current Dutch pension system. We considered abrupt and gradual retirement scenarios and showed how delaying occupational and state pension claims affects the retirement replacement rates and the implied pension wealth. Several studies have suggested that supplementing the (part-time) retirement income with part-time work income after the standard retirement age can ease the pressure on the pension system caused by population ageing ${ }^{45}$ and our analysis shows that the current pension system in the Netherlands in principle provides such opportunities for gradual retirement. This implies that the apparent labour market restrictions that may prevent

\footnotetext{
${ }^{44}$ Whitehouse (2006).

${ }^{45}$ Laczko (1988); Chen (1996); Cahill et al. (2006); Robinson and Clark (2010).
} 
employees from taking up a gradual retirement arrangement in the Netherlands stem from other causes than the pension system, for example, restrictions on part-time work opportunities imposed by employers, or employer attitudes that make working longer unattractive or impossible. ${ }^{46}$

Our baseline analysis of the replacement rates shows that partial retirement instead of full retirement results in a much smoother income path before age 65 and encourages employees to defer their pension rights beyond age 65. Although the occupational pension system gives actuarially fair rewards for working longer, the state pension and the tax system make working longer less attractive, leading to negative net total pension wealth accruals. This distortion is stronger for abrupt retirement than for gradual retirement scenarios.

The analysis of alternatives to the benchmark employee shows, first of all, that the replacement rates differ substantially across the employees with different levels of work income in the cases of early and late full retirement. These changes are much less substantial in the case of partial retirement. This is also true for the changes in the service length due to interrupted careers, household composition and the occupational pension accrual rate. Second, the government's current plan of increasing the retirement age to 67 allows for about a 25 per cent decrease in the current accrual rate of the occupational pension rights while the financial well-being of a retiree at age 67 remains the same as that of a retiree at age 65 if the retirement age is not increased.

From a policy point of view, the most interesting results are probably those comparing the replacement rates for different levels of pre-retirement earnings, keeping other variables constant, such as the number of years of pension contributions at each given age. Differences are due to state pensions playing a larger role for the lower income groups, and taxes and benefits having different implications before and after retirement. For the baseline scenario of full retirement at age 65, the net replacement rates are 106, 102 and 104 per cent for low-, median- and high-income levels $(€ 15,000, € 30,000$ and $€ 60,000)$. Late retirement (age 70) is financially more attractive for the higher income group whose replacement rate would change from 104 to 156 than for the lower and medium income groups, whose replacement rates would change from 106 to 146 and from 102 to 140, respectively. This shows that the current system with flexible and actuarially fair occupational pensions unintentionally has a larger incentive to retire later for the highest income groups (even keeping the number of years employees have contributed to the pension fund constant).

Similarly, we can compare the incentives of the three income groups to retire partially and work half time from age 65 to age 70 . For the median income group, this gives replacement rates 116 and 125 during partial and full retirement corresponding to a weighted (lifetime after 65) average of about 122, an increase of 20 percentage points compared with the baseline (102 for full retirement at age 65). For the lower income group, the replacement rates are 115 and 127 for a lifetime average of about 123, coming from a baseline of 106, so that this partial retirement scenario seems relatively less attractive for the low incomes. For the high-income group the replacement rates are 117 and 136 during partial and full retirement for a lifetime average of about 130,

\footnotetext{
${ }^{46}$ van Dalen and Henkens (2005).
} 
compared with 104 at baseline, giving them a clearly larger advantage than both other groups. More flexibility and actuarial neutrality of occupational pensions will therefore benefit the higher income groups more than the lower incomes when other features of the institutions driving replacement rates in terms of disposable income are taken into account.

In future research it seems worthwhile to conduct a similar analysis on replacement rates using data on actual workers, exploiting the available administrative data on labour income and pension entitlements. Such an analysis allows identifying the variation in replacement rates in the population and its possible determinants. Moreover, it seems useful to study whether factors other than the pension system hamper flexible and gradual retirement opportunities that can explain why gradual retirement in the Netherlands is less common than in many other countries.

\section{Acknowledgements}

This study is funded by the Network for Studies on Pensions, Aging and Retirement (Netspar) under Grant Number N2010.115. The views expressed in this paper are those of the authors and not of Netspar. We thank Johannes Binswanger, Monika Bütler, Gerry Dietvorst, Angela Forch, Loes Frehen, Kéne Henkens, Adriaan Kalwij, Ron Linssen, Mauro Mastrogiacomo, Wim Moes, Eduard Ponds, Tim Schulteis, Kerstin Thoma, Jan-Maarten van Sonsbeek, Frederic Vermeulen, Hasse Vleeming, and three anonymous reviewers for their useful comments and assistance in our calculations.

\section{References}

Alessie, R. and Kapteyn, A. (2001) 'Savings and pensions in the Netherlands', Research in Economics 55(1): $61-82$.

Alessie, R., Kapteyn, A. and Klijn, F. (1997) 'Mandatory pensions and personal savings in the Netherlands', De Economist 145(3): 291-324.

Belastingdienst (2010a) Loonheffingen. Handboek.

Belastingdienst (2010b) Toelichting zorgtoeslag. Handboek.

Belloni, M., Monticone, C. and Trucchi, S. (2006) Flexibility in Retirement. A Framework for the Analysis and a Survey of European Countries. Research report commissioned by the European Commission, CeRP, Turin.

Bovenberg, A.L. (2008) 'The life-course perspective and social policies: An overview of the issues', CESifo Economic Studies 54(4): 593-641.

Brown, K.N. and Schieber, S.J. (2003) Structural Impediments to Phased Retirement, Arlington, VA: Watson Wyatt Worldwide.

Brückner, H. and Mayer, K.U. (2005) 'De-standardization of the life course: What it might mean? And if it means anything, whether it actually took place?' Advances in Life Course Research 9: 27-53.

Cahill, K.E., Giandrea, M.D. and Quinn, J.F. (2006) 'Retirement patterns from career employment', The Gerontologist 46(4): 514-523.

Chen, Y.-P. (1996) 'The role of the fourth pillar in the redesign of social security', The Geneva Papers on Risk and Insurance-Issues and Practice 21(October): 469-477.

Chen, Y.-P. and Scott, J.C. (2003) 'Gradual retirement: An additional option in work and retirement', North American Actuarial Journal 7(3): 62-74.

Delsen, L. and Reday-Mulvey, G. (1996) Gradual Retirement in OECD Countries: Macro and Micro Issues and Policies, Aldershot, UK: Dartmouth Publishing Company Ltd.

Dunnewijk, B. (2002) 'Four pillars, four solutions: Pension reform and insurance opportunities', The Geneva Papers on Risk and Insurance-Issues and Practice 27(4): 540-554. 
Engelhardt, H. (2012) 'Late careers in Europe: Effects of individual and institutional factors', European Sociological Review 28(4): 550-563.

Euwals, R., van Vuuren, D. and Wolthoff, R. (2010) 'Early retirement behaviour in the Netherlands: Evidence from a policy reform', De Economist 158(3): 209-236.

Forman, J.B. and Scahill, P.L. (2003) 'Issues for implementing phased retirement in defined benefit plans', North American Actuarial Journal 7(3): 75-84.

Fouarge, D. and Huynen, B. (2005) 'Inkomenseffecten van uittreding', in Centraal Bureau voor de Statistlek, Tijdschrifttitel Sociaal-economische Trends: Statistisch Kwartaalblad Over Arbeidsmarkt, Sociale Zekerheid en Inkomen, aflevering 1, Utrecht: Centraal Bureau voor de Statistiek, pp. 49-56.

Goudswaard, K.P., Beetsma, R.M.W.J., Nijman, T.E. and Schnabel, P. (2010) Een sterke tweede pijler: Naar een toekomstbestendig stelsel van aanvullende pensioenen, Rapport van de commissie toekomstbestendigheid aanvullende pensioenregelingen, Den Haag.

Gruber, J. and Wise, D. (eds) (2004) Social Security Programs and Retirement around the World: Micro-Estimation, Chicago: University of Chicago Press.

Hurd, M.D. (1996) 'The effect of labor market rigidities on the labor force behavior of older workers', in D.A. Wise (ed.) Advances in the Economics of Aging, Chicago: University of Chicago Press, pp. 11-60.

Hutchens, R. (2010) 'Worker characteristics, job characteristics, and opportunities for phased retirement', Labour Economics 17(6): 1010-1021.

Kantarc1, T., Smeets, I. and van Soest, A. (2011) Implications of full and partial retirement for replacement rates in a defined benefit system. Netspar Discussion Paper No. 05/2011-045.

Kantarc1, T. and van Soest, A. (2008) 'Gradual retirement: Preferences and limitations', De Economist 156(2): $113-144$.

Knoef, M., Alessie, R. and Kalwij, A. (2009) Changes in the income distribution of the Dutch elderly between 1989 and 2020: A microsimulation. Netspar Discussion Paper No. 09/2009-030.

Laczko, F. (1988) 'Partial retirement: An alternative to early retirement? A comparison of phased retirement schemes in the United Kingdom, France and Scandinavia', International Social Security Review 41(2): 146-169.

Latulippe, D. and Turner, J. (2000) 'Partial retirement and pension policy in industrialized countries', International Labour Review 139(2): 179-195.

McGill, D.M., Brown, K.N., Haley, J.J. and Schieber, S.J. (2005) 'Changing the end of work: Phased retirement', in Fundamentals of Private Pensions. Chapter 20, New York: Oxford University Press, pp. 552-591.

Ministerie van Sociale Zaken en Werkgelegenheid (2008) Beslispunten flexibilisering AOW, Nota.

Moen, P. and Sweet, S. (2004) 'From “work-family" to "flexible careers", Community, Work \& Family 7(2): 209-226.

Munzenmaier, F. and Paciero, J. (2002) 'Replacement ratios and phased retirement-A new tune on an old fiddle', Benefits Quarterly 18(1): 7-14.

Murphy, K.M. and Welch, F. (1990) 'Empirical age-earnings profiles', Journal of Labor Economics 8(2): $202-229$.

OECD (2011) Pensions at a Glance 2011: Retirement-income Systems in OECD and G20 Countries, Paris: OECD Publishing.

Reday-Mulvey, G. (2000) 'Gradual retirement in Europe', Journal of Aging and Social Policy 11(2-3): 49-60.

Reday-Mulvey, G. (2002) 'Main achievements of the four pillars programme', The Four Pillars Newsletter No. 31: 2-7.

Robinson, C. and Clark, R. (2010) 'Retiree health insurance and disengagement from a career job', Journal of Labor Research 31(3): 247-262.

Rohwedder, S. and Willis, R.J. (2010) 'Mental retirement', Journal of Economic Perspectives 24(1): 119-138.

Scahill, P.L. and Forman, J.B. (2004) 'Phased retirement for defined benefit plan participants', Journal of Actuarial Practice 11: 43-62.

Stichting Pensioenfonds ABP (2009) Jaarverslag, Handboek.

Stichting Pensioenfonds ABP (2010a) Overzicht premies en franchises, Handboek.

Stichting Pensioenfonds ABP (2010b) Pensioenreglement, Handboek.

van Dalen, H.P. and Henkens, K. (2005) 'The double standard in attitudes toward retirement-The case of the Netherlands', The Geneva Papers on Risk and Insurance -Issues and Practice 30(4): 693-710.

van Sonsbeek, J.-M. (2010) 'Micro simulations on the effects of ageing-related policy measures', Economic Modelling 27(5): 968-979.

Wadensjö, E. (2006) 'Part-time pensions and part-time work in Sweden', European Papers on the New Welfare. Paper No. 6(October): 29-45.

Whitehouse, E. (2006) 'New indicators of 30 OECD countries' pension systems', Journal of Pension Economics and Finance 5(3): 275-298. 


\section{About the Authors}

Tunga Kantarcı is post-doctoral researcher at Radboud University, The Netherlands. He holds a PhD in Econometrics from Tilburg University. His main research interests are applied micro-econometrics, labour economics, health economics and experimental economics. He is fellow of Netspar, the Dutch Network for Studies on Pensions, Aging and Retirement.

Ingrid A.J. Smeets is senior actuary (AG) in the Governing Board Advice department of APG. She holds a master's degree in Actuarial Science. In 1996 she started working as a consultant for the legal predecessor of Towers Watson in the Netherlands and in 1999 she switched to DSM Pension Services. She joined ABP in 2007. As of March 2008, ABP split up its administration and investment department from the pension fund into a new company, the APG Algemene Pensioen Groep N.V. (APG). She continued her activities from that time as an employee of APG.

Arthur van Soest is Professor of Econometrics at Tilburg University, The Netherlands, Department of Econometrics and Operations Research. He holds a PhD in Economics, also from Tilburg University. He previously worked for the RAND Corporation in California. His main research interests are applied microeconometrics, consumption and savings behaviour, labour economics, and health economics. He is affiliated with Netspar, the Dutch Network for Studies on Pensions, Aging and Retirement. 